\title{
ARTICLE
}

\section{Bacterial assemblages associated with coral species of the Mexican Central Pacific}

\author{
Ensamblajes bacterianos asociados a especies de \\ coral del Pacífico central mexicano \\ Joicye Hernández-Zulueta ${ }^{1,2}$, Leopoldo Díaz-Pérez ${ }^{2}$, Rubén Araya ${ }^{3}$, \\ Ofelia Vargas-Ponce ${ }^{4}$, Alma P. Rodríguez-Troncoso ${ }^{5}$, \\ Eduardo Ríos-Jara ${ }^{2}$, Marco Ortiz ${ }^{3}$ and \\ Fabián A. Rodríguez-Zaragoza ${ }^{2 *}$
}

\begin{abstract}
${ }^{1}$ Programa de Doctorado en Ciencias en Biosistemática, Ecología y Manejo de Recursos Naturales y Agrícolas (BEMARENA), Centro Universitario de Ciencias Biológicas y Agropecuarias, Universidad de Guadalajara, Camino Ramón Padilla Sánchez No. 2100, Nextipac, Zapopan, Jalisco, CP 45110, México

${ }^{2}$ Laboratorio de Ecosistemas Marinos y Acuicultura, Departamento de Ecología, Centro Universitario de Ciencias Biológicas y Agropecuarias, Universidad de Guadalajara, Camino Ramón Padilla Sánchez No. 2100, Nextipac, Zapopan, Jalisco, CP 45110, México. *rzf39259@cucba.udg.mx

${ }^{3}$ Instituto de Ciencias Naturales 'Alexander Von Humboldt', Instituto Antofagasta, Universidad de Antofagasta, P.O. Box 170, Antofagasta, Chile

${ }^{4}$ Departamento de Botánica y Zoología, Centro Universitario de Ciencias Biológicas y Agropecuarias, Universidad de Guadalajara, Camino Ramón Padilla Sánchez No. 2100, Nextipac, Zapopan, Jalisco, CP 45110, México

${ }^{5}$ Laboratorio de Ecología Marina, Centro Universitario de la Costa, Universidad de Guadalajara, Av. Universidad 203, Del. Ixtapa, Puerto Vallarta, Jalisco, CP 48280, México
\end{abstract}

Resumen.- El papel funcional de las bacterias asociadas a corales y su contribución a la salud del coral es aún desconocido en gran medida. Es necesario que primero se caracterice el ensamblaje microbiano del coral y sus cambios en la diversidad a través de las especies de coral, el espacio y tiempo. Los corales ramificados (e.g., género Pocillopora) son los principales constructores arrecifales a nivel mundial. Este estudio evaluó la estructura bacteriana asociada al mucus y tejidos de Pocillopora damicornis y Pocillopora verrucosa, así como del agua de mar y sedimentos circundantes en 6 sitios del Pacífico central mexicano. Se emplearon las técnicas DGGE y RFLP del ADNr 16 S para generar los perfiles de bandeo o evaluar la diversidad. Además, se evaluó la relación del ensamblaje bacteriano-coral con variables ambientales y espaciales del entorno arrecifal (de cada sitio), utilizando análisis multivariados. Se obtuvieron 20 Unidades Taxonómicas Operacionales (OTU) diferentes, siendo los sedimentos los que presentaron mayor número. Se encontró una especificidad de grupos bacterianos para cada especie de coral, así como entre el tejido y mucus de cada especie. Los resultados mostraron que los grupos de bacterias dominantes variaron entre sustratos y entre sitios, encontrando, sólo una variación espacial significativa. Las variables ambientales que explican la variación de los grupos bacterianos dominantes en corales y agua de mar fueron las coberturas de macroalgas carnosas, coral vivo y esponja. En cambio, la variación en los sedimentos fue explicada por las coberturas de arena, escombro y roca.

Palabras clave: Ensamblajes bacterianos, corales Pocillopora, variación espacio-temporal, DGGE, Pacífico mexicano

\begin{abstract}
The functional role of coral-associated bacteria and their contribution to coral health is still largely unknown. The first necessary step to address this gap in the knowledge is based on characterization of the microbial assemblage of the coral and the species-specific, temporal and spatial variation in its diversity. Branched corals (e.g., genus Pocillopora), are the main builders of coral reefs worldwide. This study evaluated the bacteria associated with the mucus and tissues of Pocillopora damicornis and Pocillopora verrucosa, as well as that of the seawater and surrounding sediments, in 6 sites of the Mexican Central Pacific during summer and winter seasons. The molecular techniques DGGE and RFLP were used with the $16 \mathrm{~S} \mathrm{rDNA}$ to assess the most abundant bacterial OTUs. The relationships between the bacterial-coral assemblage and environmental and spatial variables of the reef surroundings were also evaluated, using the multivariate analyses. Twenty different Operational Taxonomic Units (OTU) were obtained, with the highest number presented by the sediments. Specificity of bacterial groups was found for each coral species, as well as between the tissue and mucus of each species. The results showed that the bacterial dominant groups were similar between seasons, but these showed significant spatial variations among substrates within sites, as well as per substrate across all sites. The environmental variables that explained the variation of the dominant bacterial groups in corals and sea water were the coverages of fleshy macroalgae, live coral and sponge. In contrast, variation in the sediments was explained by the coverages of sand, rubble and rock.
\end{abstract}

Key words: Bacterial assemblages, Pocillopora corals, spatial-temporal variation, DGGE, Mexican Pacific 


\section{INTRODUCTION}

Coral reefs face degradation worldwide, mainly as a result of environmental stress factors of anthropogenic origin. These stresses include increased sea surface temperatures, coastal degradation, pollution, diseases and the synergistic effects of multiple stress factors (Ban et al. 2014). These changes damage the equilibrium between the coral and its associated microbiota (i.e., symbiotic dinoflagellates, endolithic algae, fungi, bacteria, archaea and viruses) (Ceh et al. 2011). It is recognized that this microbial biota plays a functional role in the daily metabolism, health, resistance, recruitment and resilience of the corals (Bourne \& Webster 2013).

Bacterial assemblages are diverse and active in coral ecosystems (Krediet et al. 2013). They are dynamic and occupy different niches: i) In the corals, within the mucus (surface mucopolysaccharide layer) (Morrow et al. 2012) and tissues (Sweet et al. 2011); ii) In the sea water (Bourne \& Munn 2005) and surrounding marine sediments (Carlos et al. 2013). However, variation in their diversity among coral species and the functional role of these bacteria remain poorly understood. Mutualistic benefits have been reported between the bacteria and corals, including fixation of nitrogen and carbon (Bourne $\&$ Webster 2013) and exchange of secondary metabolites (Littman et al. 2009), among others.

Recent research shows that the bacterial assemblage associated with the coral changes as a function of environmental conditions (Lee et al. 2012, Li et al. 2014). The corals modify their bacterial microbiota as a mechanism of acclimatization to environmental changes (Reshef et al. 2006). In order to study bacteria-coral interactions, it is necessary to determine the resident microbiota and evaluate its spatio-temporal stability (Mouchka et al. 2010). Certain studies report that each coral species presents specific bacterial assemblages, regardless of geographic distance (Bourne \& Webster 2013, Krediet et al. 2013).

Culture-independent techniques, such as denaturing gradient gel electrophoresis (DGGE), restriction fragment length polymorphism (RFLP), clone libraries and sequencing of 16SrDNA, have identified a wide range of bacterial groups associated with the corals (Littman et al. 2009). Recently, massive sequencing has provided greater knowledge of the bacteria associated with corals and is used for studies of microbial ecology (Li et al. 2014). Moreover, DGGE (Muyzer et al. 1993 ) is widely used to estimate the bacterial structure and diversity associated with marine invertebrates (RodríguezLanetty et al. 2013). This technique is relatively straight forward, highly reproducible, rapid and reliable and thus represents an attractive alternative for the analysis of the bacterial assemblages in environmental samples.
This study represents the first comparative analysis of bacterial assemblages associated with coral ecosystems and uses two coral species of wide distribution in the Mexican Central Pacific (MCP) as a case study. This region is characterized by the presence of an important richness and live coverage of corals, where those of the genus Pocillopora constitute the main reef builders (Reyes-Bonilla et al. 2013). Furthermore, it is an area with excellent representation of the coral ecosystems of the northern sector of the Eastern Tropical Pacific. The objective of this study was to analyze spatio-temporal variation in the assemblage of dominant bacterial groups associated with the mucus and tissue of Pocillopora damicornis and Pocillopora verrucosa, sea water and sediments in the MCP, as well as to correlate the variation in the diversity with environmental variables of the ecosystem.

\section{MATERIALS AND METHODS}

\section{STUDY AREA AND SAMPLING}

The MCP includes the coast of the states of Nayarit, Jalisco and Colima in Mexico (Fig. 1A). It is characterized by the presence of relatively productive waters in a transition zone of 3 oceanic currents: i) the Costa Rica Coastal Current (CRCC), which brings warm water from the south; ii) the California Current (CC), which carries cold water rich in nutrients in a north-south direction; and iii) the Gulf of California Current. This allows the occurrence of 3 seasons per year (Wyrtki 1966). Samples were taken in August 2013 and January 2014 in 6 sites along the MCP: i) Costa Fragata Somero (CFS) in Isla Isabel, which is located to the north and in the mouth of the Gulf of California (Fig. 1B); ii) Zona de Restauración (ZR) in the Islas Marietas, located in the northeast of Bahía de Banderas (Fig. 1C); iii) Pelícanos (P) in Bahía Chamela, located on the central coast of Jalisco (Fig. 1D); iv) Cuastecomatito (CU) in Bahía Cuastecomates-Punta Melaque, located on the southern coast of Jalisco (Fig. 1E); v) Carrizales (CRZ) in Bahía Ceníceros; and vi) Punto B (PB) in Bahía Santiago, both found in Colima (Fig. 1F).

Samples were taken in 3 apparently healthy colonies of $P$. damicornis and $P$. verrucosa from between 1 and $6 \mathrm{~m}$ in depth at each site (Fig. 1). From each colony, a fragment of length 2$3 \mathrm{~cm}$ was collected and placed in a sterile plastic bag with sea water for transportation to land. Mucus was collected from each fragment with a sterile cotton bud and stored in a $2 \mathrm{ml}$ cryovial with sterile sea water (Guppy \& Bythell 2006). Tissue was obtained by removal with pressurized air at ambient temperature (Bourne \& Munn 2005). Samples were preserved in liquid nitrogen until subsequent processing. In addition, triplicate 
samples of the sea water were taken at each site using KIMAX sterile glass bottles at a distance of $\sim 10 \mathrm{~cm}$ from each coral colony. The sea water was filtered with Sterivex nitrocellulose membranes of $0.22 \mathrm{~mm}$ (Millipore, Billerica). Finally, triplicate samples of the sediment were taken at each site, using $50 \mathrm{ml}$ conical polypropylene tubes at $\sim 10 \mathrm{~cm}$ from the colonies. The filters with the microorganisms retained from the sea water and the sediment samples were preserved in liquid nitrogen for transportation to the laboratory.

\section{DNA EXTRACTION AND PURIFICATION}

The DNA was extracted from the sea water and sediment samples using the kit UltraCleanSoil DNA (MoBio, Carlsbad, $\mathrm{CA})$. The DNA of the mucus and tissue was obtained using the modified protocol of Ausubel (2002). Purification of the DNA was performed with the kit Wizard DNA purification (Promega, Madison, WI). The quality and quantity of the DNA was determined with an Epoch nanodrop (260/280) and visualization was performed on $1 \%$ agarose gels. In total, DNA was extracted from 216 samples, corresponding to 36 tissues and 36 mucus

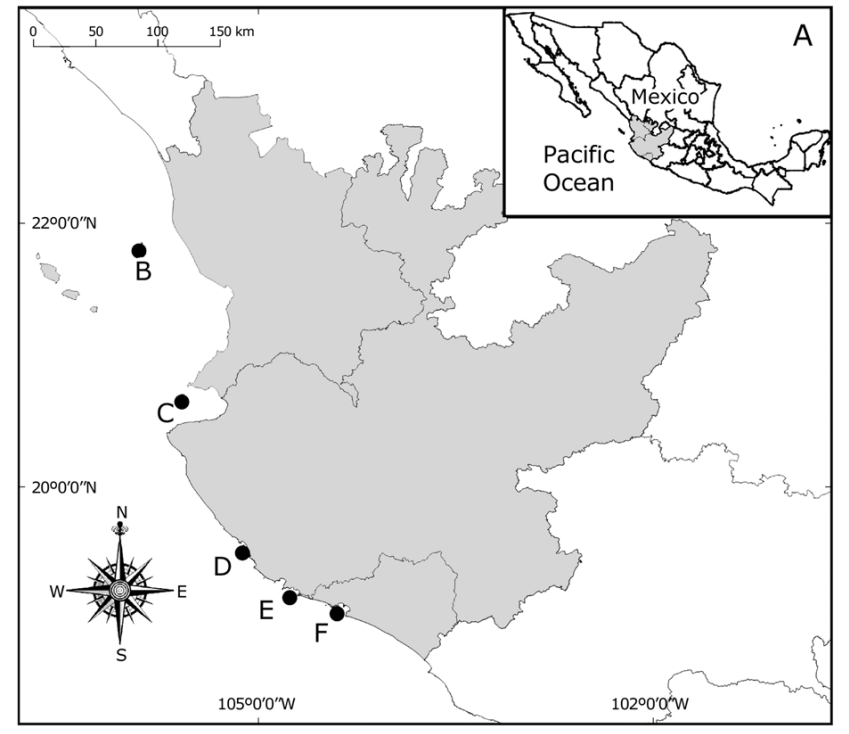

Figure 1. Study area. A) Mexican Central Pacific, B) IIN (Isla Isabel), C) IM N (Islas Marietas), Nayarit; D) BCH (Bahía Chamela), E) CUM (Bahía Cuastecomates-Punta M elaque), Jalisco; F) BCE (Bahía Ceníceros) and BSG (Bahía Santiago), Colima. CFS (Costa Fragata Somero), ZR (Zona de Restauración), P (Pelícanos), CU (Cuastecomatito), CRZ (Carrizales) and PB (Punto B) / Área de estudio. A) Pacífico central mexicano, B) IIN (Isla Isabel), C) IMN (Islas Marietas), Nayarit; D) BCH (Bahía Chamela), E) CUM (Bahía Cuastecomates-Punta Melaque), Jalisco; F) BCE (Bahía Ceníceros) y BSG (Bahía Santiago), Colima. CFS (Costa Fragata Somero), ZR (Zona de Restauración), P (Pelícanos), CU (Cuastecomatito), CRZ (Carrizales) y PB (Punto B) samples from each coral species, as well as 36 sea water and 36 sediment samples.

\section{PCR AMPLIFICATION OF 16S RDNA}

Amplification of the $16 \mathrm{~S}$ rDNA was performed with universal primers 27f (52-GAGTTTGATCCTGGCTCAG-32) and 1525r (52-AGAAAGGAGGTGATCCAGCC-32) for bacteria (Warneke et al. 2007). The final volume per PCR reaction was $50 \mathrm{ml}$ and consisted of: $0.1 \mathrm{mM}$ of each primer, $9 \mathrm{~mL}$ of $10 \mathrm{X}$ concentrated $\mathrm{PCR}$ buffer, $50 \mathrm{mM} / \mathrm{L}$ of Tris- $\mathrm{HCl}$ at $\mathrm{pH}$ $8.2,18 \mathrm{mM} / \mathrm{L}$ of $\mathrm{MgCl}_{2}, 500 \mathrm{mM} / \mathrm{L} \mathrm{KCl}, 2 \mathrm{ml}$ of DNTPs (10 $\mathrm{mM} / \mathrm{L}), 1 \mathrm{~mL}$ of DNA at $5 \mathrm{mM}, 1.25 \mathrm{U}$ of GoTaqFlexi DNA polymerase (Promega, Madison WI) and double distilled water. Amplification was performed in a Apollo DNA Cycler® thermocycler (NyxTechnik Inc.) under the following conditions: $94^{\circ} \mathrm{C}$ for $2 \mathrm{~min}$, followed by 35 cycles of $94^{\circ} \mathrm{C}$ for $30 \mathrm{~s}, 55^{\circ} \mathrm{C}$ for $30 \mathrm{~s}$ and $72^{\circ} \mathrm{C}$ for $2 \mathrm{~min}$, after which a final elongation step at $72^{\circ} \mathrm{C}$ for $10 \mathrm{~min}$ was performed. The PCR products were purified with the Wizard DNA purification kit (Promega, Madison, WI).
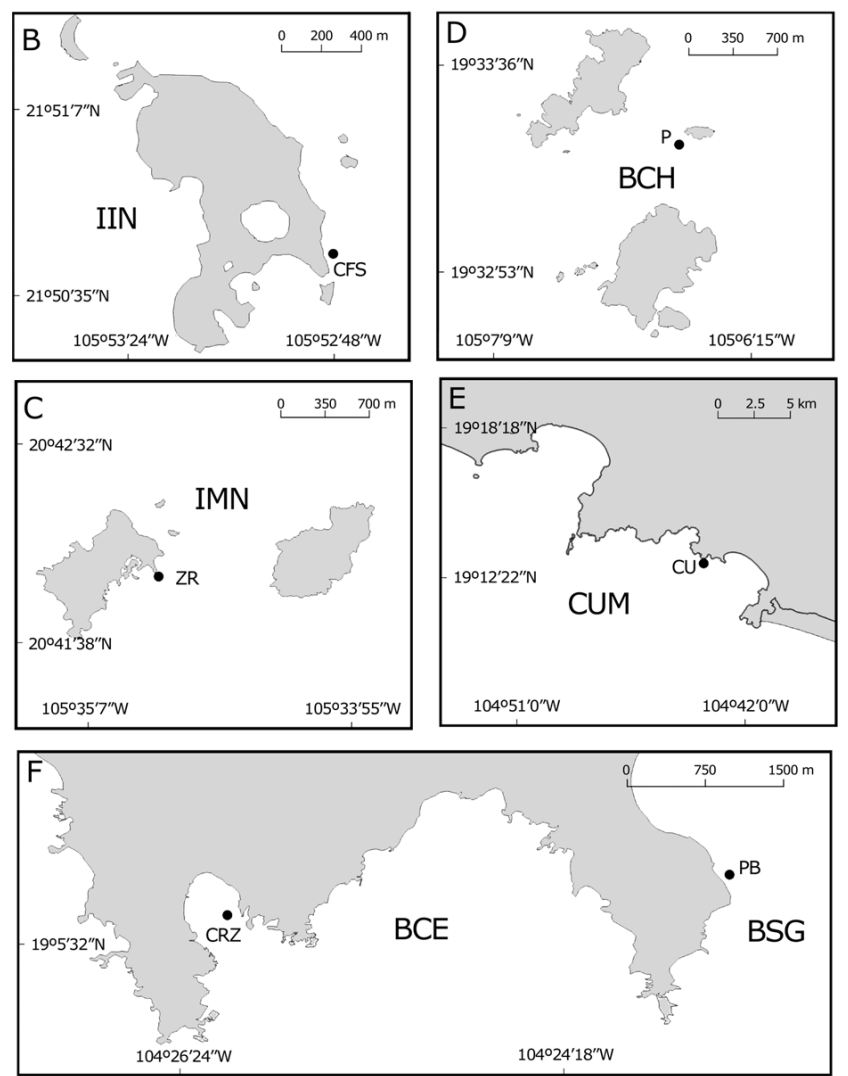


\section{DGGE ANALYSIS}

The V3 region was amplified by PCR with the primers $341 \mathrm{f}$ GC (52-CGCCCGCCGCGCGCGGCGGGCGGGGCGGG GCACGGGGGCCCTACGGGAGGCAGCAG-3') and 907r (52-CCGTCAATTCMTTTGAGTTT-3') (Muyzer et al. 1993). The reaction mixture was prepared under the same conditions as described above. Amplifications were conducted with a touchdown protocol (Ferris et al. 1996): $94^{\circ} \mathrm{C}$ for 2 min, followed by 10 cycles of $94^{\circ} \mathrm{C}$ for $30 \mathrm{~s}, 30$ cycles of $65^{\circ} \mathrm{C}$ (decreasing by $1^{\circ} \mathrm{C}$ in each cycle) and $72^{\circ} \mathrm{C}$ for $45 \mathrm{~s}$, followed by 20 cycles of $94^{\circ} \mathrm{C}$ for $30 \mathrm{~s}, 55^{\circ} \mathrm{C}$ for $30 \mathrm{~s}$ and $72^{\circ} \mathrm{C}$ for 45 s $2 \mathrm{~min}$, after which a final elongation step at $72^{\circ} \mathrm{C}$ for $5 \mathrm{~min}$.

The PCR products were analyzed in a DGGE TTGEK2401-220 (CBS Scientific Company) system. The PCR products were run on $8 \%$ acrylamide gels with a 30-70\% linear gradient of urea-formamide, using $1 \mathrm{X}$ TAE buffer. Electrophoresis was conducted at $60^{\circ} \mathrm{C}$ and 70 volt for $16 \mathrm{~h}$. Gels were removed and stained for $10 \mathrm{~min}$ with an SYBR Gold nucleic acid stain (Molecular Probes Inc., Eugene, OR) in 1XTAE buffer. Gels were distained by rinsing with $1 \mathrm{X}$ TAE buffer and subsequently photographed using a UV transilluminator.

\section{RFLP ANALYSIS}

The PCR amplifications products of 16S rDNA were digested with the restriction enzymes Alu I (Promega) and Hae III (Promega). The restriction reactions for both enzymes were prepared with NEB Buffer 2 (Promega), 10U of the enzyme and $15 \mathrm{ml}$ of PCR product. The samples were incubated at $37^{\circ} \mathrm{C}$ for $6 \mathrm{~h}$ and analyzed in $1.5 \%$ agarose gels in $1 \mathrm{X} \mathrm{TAE}$ buffer at 85 volt for $40 \mathrm{~min}$ (Grimont \& Grimont 1986).

\section{ENVIRONMENTAL VARIABLES}

Measurements were taken in triplicate of sea surface temperature (SST), dissolved oxygen and salinity with the probes YSI-55 and YSI-30. In order to estimate the concentration of ammonium, nitrate + nitrite, phosphate and silicate, three sea water samples were taken (in $30 \mathrm{ml}$ Sarstedt polypropylene tubes) per site. These samples were filtered with $2.5 \mathrm{~cm}$ fiberglass discs of pore size $0.2 \mathrm{~mm}$ (GF/F Whatman), which had been previously oven-treated for 2 to $3 \mathrm{~h}$ at $450^{\circ} \mathrm{C}$. These were then placed in sterile $30 \mathrm{ml}$ polypropylene jars and stored at $-25^{\circ} \mathrm{C}$ until subsequent processing in a Skalar Flowanalyzer CFA SAN plus nutrient analyzer. Granulometry (determination of percentage of gravel, sand, clays and silt) was performed in the sediments following the method of Buoyocoz (1928).
The benthic structure was recorded in the sampling sites using 3 linear transects, each of $20 \mathrm{~m}$ in length. Along each transect, 5 quadrats of $1 \mathrm{~m}^{2}$ were placed equidistantly $(\sim 5 \mathrm{~m})$ to record the coverage of hermatypic corals, soft corals, hydrocorals, articulated and encrusting calcareous algae, fleshy macroalgae, rubble, rock, sand, dead coral and algal turfs.

\section{STATISTICAL ANALYSIS}

One-way analyses of similarity (ANOSIM), based on Sorensen similarity matrices, were conducted to evaluate variation in the number of Operational Taxonomic Units (OTU) among Seasons (SE, 2 levels: Summer and Winter), Sites (SI, 6 levels: Costa Fragata Somero, Zona de Restauración, Pelícanos, Cuastecomatito, Carrizales and Punto B) and Substrates (SU, 6 levels: mucus and tissue of $P$. damicornis and $P$. verrucosa, sea water and sediments). Likewise, other ANOSIM were calculated to contrast the variation in the OTUs among sites per substrate type, as well as among the substrates within each site. Statistical significance was tested with 9.999 permutations in Primer V6.1+PERMANOVA (Clarke \& Gorley 2006).

Presence/absence matrices were constructed with the DGGE and RFLP banding profiles to perform non-metric multidimensional scaling (NMDS) analysis, based on Sorensen similarities (Clarke \& Gorley 2006). The DGGE matrix was used to determine the similarity of the bacterial assemblages for each of the substrates among all of the sampling sites, as well as to estimate the similarity of the assemblages of all the substrates for each sampling site (local level). The RFLP matrix served to corroborate the findings of the NMDS analysis of the DGGE matrix.

The relationship between the bacterial assemblage and the environmental-spatial variables was evaluated with canonical additive partitions, based on canonical correspondence analysis (CCA), assuming a unimodal relationship among them (Legendre \& Legendre 1998). The biological variables corresponded to the $Y$ matrices constructed with the number of OTUs present. The $X$ matrices were constructed with all of the aforementioned environmental variables. With the spatial variables, a $W$ matrix was constructed using a superficial trend analysis based on geographic coordinates in UTM represented as a third order polynomial (Legendre \& Legendre 1998). The CCA identified which $X$ and $W$ variables best explained the variation of $Y$. The models were conducted at the level of sites based on the results of the ANOSIM. The Trace statistic was used to analyze the fit of the model, since it represents the variation of $Y$ explained by all of the canonical axes. In order to reduce multicollinearity among predictive variables, Pearson correlations ( $r$ ) were used, eliminating those with $r \geq 0.90$. 
Likewise, a variance inflation factor (VIF) $\leq 10$ was used. Statistical significance was tested with 9.999 permutations under a reduced model in CANOCO v4.5 (Ter Braak \& Smilauer 2002).

\section{ReSUlts}

\section{DGGE PATTERNS}

The DGGE banding pattern showed 7 to 13 bands per sample with a total of 20 bands. It was assumed that each band observed corresponded to one OTU. The highest number of bands (13) was found in the sediments of Costa Fragata Somero and Zona de Restauración in summer and winter, and in Pelícanos in winter. In the tissue of $P$. damicornis of Costa Fragata Somero, Zona de Restauración, Pelícanos and Cuastecomatito, 12 bands were observed. The lowest number was found in the sea water of Costa Fragata Somero and Zona de Restauración (7), Pelícanos and Cuastecomatito (8) (Appendix A, Table A1). The banding profiles (DGGE) of the bacterial assemblage in the tissues and mucus of $P$. damicornis and $P$. verrucosa, sea water and sediment differed among some sites, while the banding pattern among the replicates of the substrates was identical (Appendix A, Fig. A1). However, none of the sites presented the total number of bands found (20 OTUs). Some were exclusive; 17 bands in sea water and sediments, 18, 19 and 20 in sediments. In contrast, 2, 7, 10 and 14 bands were present in most of the substrates and sites, with the exception of sea water (Appendix A, Table A1).

\section{VARIATION IN THE BACTERIAL ASSEMBLAGES}

The ANOSIM showed significant spatial variations in the composition of bacterial OTUs among sites and substrates, but did not show significant temporal variation (Appendix B, Table B1). The pairwise comparisons of the factor Substrate showed significant differences. In contrast, in the factor Site, it was observed that most of the sites have a particular bacterial assemblage, except between Costa Fragata Somero and Zona de Restauración. In terms of OTU, the most similar sites were Carrizales and Punto B. These sites were also those most dissimilar to the rest of the sites (Appendix B, Table B1).
Figure 2. Nonmetric multidimensional scaling (NMDS) of the substrates among the sites from Mexican Central Pacific. A) P. damicornis tissue; B) P. verrucosa tissue; C) P. damicornis mucus; D) P. verrucosa mucus; E) Sea water and F) Sediments. Codes: CFS (Costa Fragata Somero), ZR (Zona de Restauración), P (Pelícanos), CU (Cuastecomatito), CRZ (Carrizales) and PB (Punto B) / Ordenamiento multidimensional no métrico (NMDS) de los sustratos entre los sitios del Pacífico central mexicano. A) Tejido de P. damicornis; B) Tejido de P. verrucosa; C) Mucus de P. damicornis; D) Mucus de P. verrucosa; E) Agua de mar y F) Sedimentos. Códigos: CFS (Costa Fragata Somero), ZR (Zona de Restauración), P (Pelícanos), CU (Cuastecomatito), CRZ (Carrizales) y PB (Punto B)
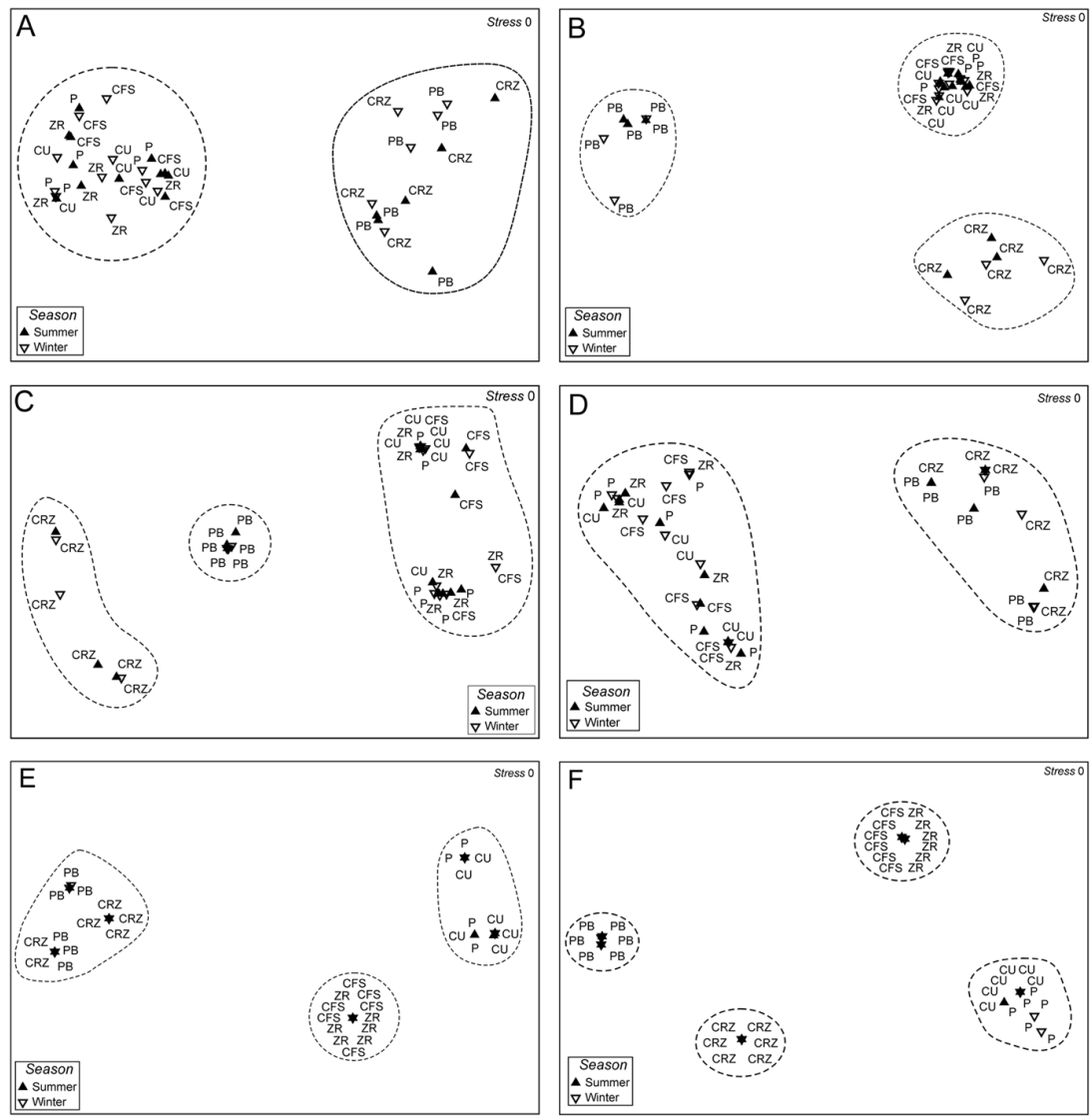

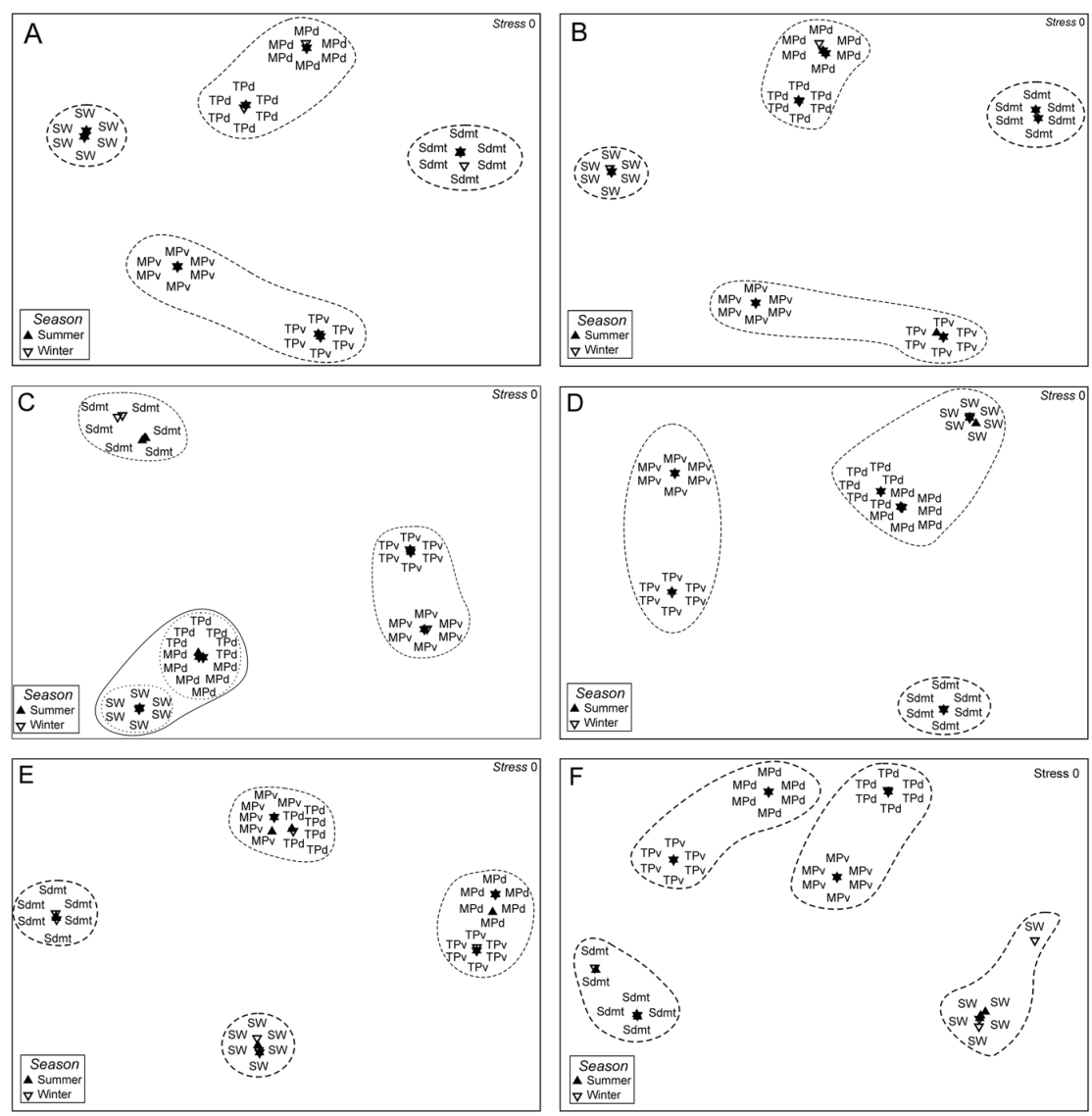

\begin{abstract}
Figure 3.Non-metric multidimensional scaling (NM DS) of the substrates within the sites from Mexican Central Pacific. A) Costa Fragata Somero, B) Zona de Restauración, C) Pelícanos, D) Cuastecomatito, E) Carrizales and F) Punto B. Code: TPd (P. damicornis tissue), TPv (P. verrucosa tissue), MPd (P. damicornis mucus), MPv (P. verrucosa mucus), SW (Sea water) and Sdmt (Sediments) / Ordenamiento multidimensional no métrico (NMDS) de los sustratos dentro de los sitios del Pacífico central mexicano. A) Costa Fragata Somero, B) Zona de Restauración, C) Pelícanos, D) Cuastecomatito, E) Carrizales y F) Punto B. Códigos: TPd (Tejido de P. damicornis), TPv (Tejido de P. verrucosa), MPd (Mucus de P. damicornis), MPv (Mucus de P. verrucosa), SW (Agua de mar) y Sdmt (Sedimentos)
\end{abstract}

Analysis of each substrate at regional level showed significant differences among sites (Appendix B, Tables B2). The pairwise comparisons of the OTUs of $P$. damicornis tissues and $P$. verrucosa mucus showed that Costa Fragata Somero, Zona de Restauración, Pelícanos and Cuastecomatito are similar in composition of bacterial OTUs, but differ in this regard to Carrizales and Punto B in Colima. The bacterial assemblage of these latter sites did not present variation. In the $P$. verrucosa tissues and $P$. damicornis mucus, the composition of the microbiota of the sites in Nayarit and Jalisco were similar to each other and different to those of Colima, which also presented differences among themselves. The pairwise comparisons on the sea water samples showed that the bacterial assemblages of the sites belonging to the same state did not present significant differences. In the sediments, significant differences were found in the composition of OTUs in most of the sites, except for
Costa Fragata Somero $v s$.Zona de Restauración in Nayarit (Appendix B, Table B2).

The NMDS ordination of the tissue samples of $P$. damicornis showed that Punto B and Carrizales were more similar in term of OTU, but also dissimilar to the rest of the sites (Fig. 2A). In contrast, the tissue samples of $P$. verrucosa showed that Carrizales and Punto B were dissimilar to each other and to the rest of the sites (Fig. 2B). The composition of OTUs of the tissue samples of both coral species was similar for the sites that corresponded to the states of Jalisco and Nayarit, but different to those of Colima (Fig. 2A-B). In the mucus of $P$. damicornis, greater similarity of OTU was observed among the sites from Jalisco and Nayarit, but these differed to those of Carrizales and Punto B, with the latter sites also found to be different to each other (Fig. 2C). The mucus samples of $P$. 

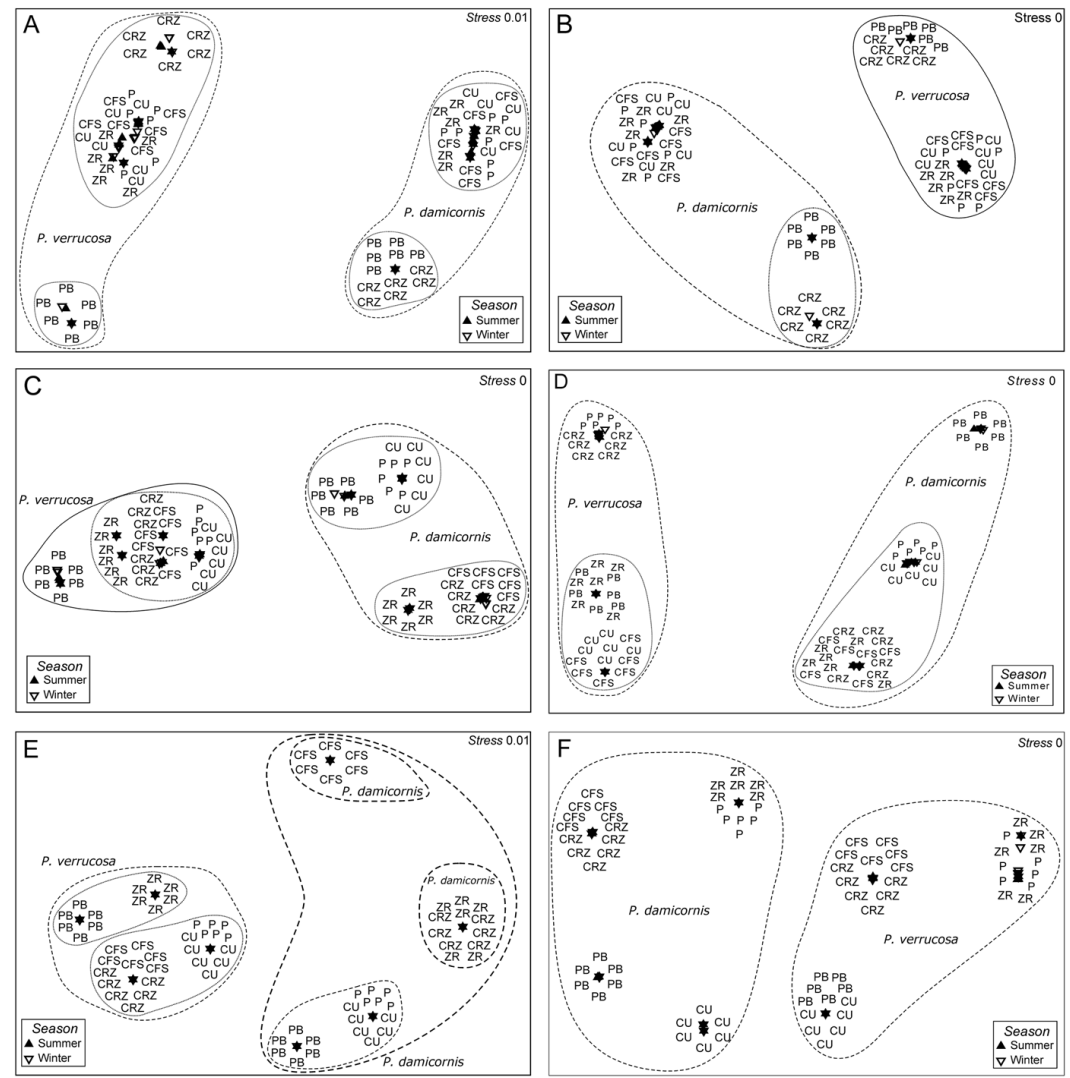

Figure 4. Non-metric multidimensional scaling (NMDS) of the operational taxonomic units (OTUs) in the tissue (A, $C$ and $E$ ) and mucus (B, D and F) of P. damicornis and P. verrucosa. A-B) Denaturing Gradient Gel Electrophoresis (DGGE), C-D) Restriction Fragment Length Polymorphism (RFLP) with the enzyme Alu I and, E-F) RFLP with the enzyme Hae III. CFS (Costa Fragata Somero), ZR (Zona de Restauración), P (Pelícanos), CU (Cuastecomatito), CRZ (Carrizales) and PB (Punto B) / Ordenamiento multidimensional no métrico (NMDS) de las unidades taxonómicas operacionales (OTUs) en los tejidos ( $A, C$ y $E$ ) y mucus (B, D y F) de P. damicornis y $P$. verrucosa. A-B) Electroforesis en gel con gradiente desnaturalizante (DGGE), C-D) Polimorfismo de longitud de fragmentos de restricción (RFLP) con la enzima Alu I y, E-F) RFLP con la enzima Hae III. CFS (Costa Fragata Somero), ZR (Zona de Restauración), P (Pelícanos), CU (Cuastecomatito), CRZ (Carrizales) y PB (Punto B)

verrucosa did not show differences between Carrizales and Punto B, but both were different to the rest of the sites, which were similar to each other in terms of OTU (Jalisco and Nayarit) (Fig. 2D). In the sea water, 3 groupings were observed in the NMDS. The samples of the sites of each state were more similar to each other, but differences were evident in the composition of OTUs among sites of different states (Fig. 2E). In the sediment, a pattern similar to that of the sea water samples was found, except that the sites from Colima (Carrizales and Punto B) were different (Fig. 2F).

The results of the ANOSIM provided evidence that the composition of bacterial OTUs differed among the substrates of the sites. The pairwise comparisons showed a specificity of bacterial assemblage per substrate (Appendix B, Table B3). The NMDS of these analyses showed a similar pattern in all of the sites. It was found in Costa Fragata Somero, Zona de
Restauración, Pelícanos and Cuastecomatito that the tissue and mucus samples grouped themselves according to each coral species (Fig. 3A-D). However, this pattern was not observed in Carrizales and Punto B, where tissue samples of $P$. verrucosa were similar to mucus samples of $P$. damicornis and, equally, mucus samples of $P$. verrucosa were similar to tissue samples of $P$. damicornis (Fig. 3E-F). The composition of OTUs in the sediments differed to that found in coral species and sea water in each sampling site. This was similar in the sea water, with the exception of Pelícanos and Cuastecomatito, where it was observed that the composition of OTUs was more similar between the mucus and tissue of P. damicornis (Fig. 3C-D). The NMDS ordinations of the pattern of variation of DGGE bands showed that the composition of OTUs of mucus and tissue was different in both coral species (Fig. 4A-B). This was corroborated through 
the NMDS analysis of the RFLPs (enzymes Alu I and Hae III) of the DGGE banding pattern, showing separation between the species in terms of their OTU composition (Fig. 4C-F).

\section{Canonical additive Partitions}

The bacterial structure found in the tissue and mucus of both coral species, as well as in the sea water and sediments was explained only by the pure spatial component [a], since the spatial variables $(W)$ did not show a significant relationship to the bacterial OTUs. For this reason, the spatially structured [b] and purely spatial [c] environmental variation did not contribute in the analyses. The total explained variation $[a+b+c]$ ranged from 78.06 to $95.37 \%$, with statistical significance values of between $0.0001<P<0.0344$ (Table 1 ). In the mucus of $P$. damicornis and tissue of $P$. verrucosa, the variables that explained the variation of the composition of the bacteria were coverage of live coral, sponges and fleshy macroalgae (Table 1). These variables also explained the variation in the composition of the bacterial OTUs of the tissue of $P$. damicornis, mucus of $P$. verrucosa and sea water, but with the inclusion of salinity. In contrast, the variation in the sediments was explained by the sandy texture and coverage of sponges and live coral (Table 1). The contributions of the predictive variables of this variation are presented in Appendix B, Table B4.

\section{Discussion}

In this study, a total of 20 OTUs were observed, where each represented a bacterial species (Muyzer et al. 1993). It was found that $P$. damicornis presented a higher diversity of bacterial groups than $P$. verrucosa. Differences in the bacterial diversity among coral species have been documented in Caribbean species (Morrow et al. 2012), as well as those of the Australian Great Barrier Reef (GBR) (Kvennefors et al. 2010). However, each coral species maintains a characteristic bacterial microbiota, since they form species-specific associations with certain bacterial groups (Littman et al. 2009, McKew et al. 2012), modifying these associations in relation to stress events, such as bleaching (Bourne et al. 2008). Similarly, in the GBR, bacterial group specificity was identified in Acropora millepora (Littman et al. 2009), A. hyacinthus and Stylophora pistillata (Kvennefors et al. 2010) and, in the Mexican Caribbean, in Porites astreoides and A. palmata (McKew et al. 2012). The results of this study provide evidence that the tissue and mucus of $P$. damicornis and $P$. verrucosa have a specificity of bacterial groups that are dominant in the Mexican Central Pacific, demonstrating a species-specific coral-microbial relationship.

\begin{abstract}
Table 1. Canonical additive partition of the variation of bacterial operational taxonomic units in the different substrates in the coral reef ecosystem in the Mexican Central Pacific/ Partición aditiva de la variación de las unidades taxonómicas operacionales bacterianas en los diferentes sustratos en los ecosistemas de coral del Pacífico central mexicano
\end{abstract}

\begin{tabular}{|c|c|c|c|c|c|c|c|}
\hline & {$[a]$} & {$[b]$} & {$[c]$} & {$[d]$} & $\begin{array}{l}\text { Total. Exp } \\
{[a+b+c]}\end{array}$ & $\begin{array}{c}\text { Env. Var. } \\
\quad[a+b]\end{array}$ & $\begin{array}{c}\text { Spat. Var. } \\
{[b+c]}\end{array}$ \\
\hline \multirow[t]{2}{*}{ Tissue of Pocillopora damicornis } & 95.12 & 0.0 & 0.0 & 4.88 & $\begin{array}{c}95.12 \\
P=0.0224\end{array}$ & $\begin{array}{c}95.12 \\
P=0.0224\end{array}$ & $\begin{array}{l}0.0 \\
n . s\end{array}$ \\
\hline & Enviro & mental & riable & $\mathrm{RSC}, \mathrm{FI}$ & $\mathrm{A}, \mathrm{LCC}$ and $\mathrm{S}$ & & \\
\hline \multirow[t]{2}{*}{ Tissue of Pocillopora verrucosa } & 78.06 & 0.0 & 0.0 & 21.94 & $\begin{array}{c}78.06 \\
P=0.0107\end{array}$ & $\begin{array}{c}78.06 \\
P=0.0107\end{array}$ & $\begin{array}{l}0.0 \\
n . s\end{array}$ \\
\hline & Enviro & nental & riable & $\mathrm{RSC}, \mathrm{FI}$ & A and LCC & & \\
\hline \multirow[t]{2}{*}{ Mucus of Pocillopora damicornis } & 85.06 & 0.0 & 0.0 & 14.94 & $\begin{array}{c}85.06 \\
P=0.0343\end{array}$ & $\begin{array}{c}85.06 \\
P=0.0343\end{array}$ & $\begin{array}{l}0.0 \\
n . s\end{array}$ \\
\hline & Enviro & nental & riable & $\mathrm{RSC}, \mathrm{FI}$ & A and LCC & & \\
\hline \multirow[t]{2}{*}{ Mucus of Pocillopora verrucosa } & 86.78 & 0.0 & 0.0 & 13.22 & $\begin{array}{c}86.78 \\
P=0.0262\end{array}$ & $\begin{array}{c}86.78 \\
P=0.0262\end{array}$ & $\begin{array}{l}0.0 \\
n . s\end{array}$ \\
\hline & Enviro & nental & riable & RSC, FI & $\mathrm{A}, \mathrm{LCC}$ and $\mathrm{S}$ & & \\
\hline \multirow[t]{2}{*}{ Sea water } & 95.37 & 0.0 & 0.0 & 4.63 & $\begin{array}{c}95.37 \\
P=0.0002\end{array}$ & $\begin{array}{c}95.37 \\
P=0.0002\end{array}$ & $\begin{array}{l}0.0 \\
n . s\end{array}$ \\
\hline & Enviro & nental & riable & $\mathrm{RSC}, \mathrm{FI}$ & $\mathrm{A}, \mathrm{LCC}$ and $\mathrm{S}$ & & \\
\hline \multirow[t]{2}{*}{ Sediments } & 83.71 & 0.0 & 0.0 & 16.29 & $\begin{array}{c}83.71 \\
P=0.0235\end{array}$ & $\begin{array}{c}83.71 \\
P=0.0235\end{array}$ & $\begin{array}{l}0.0 \\
n . s\end{array}$ \\
\hline & Enviro & nental & riable & $\% \mathrm{TA}, \mathrm{F}$ & $\mathrm{SC}$ and LCC & & \\
\hline \multicolumn{8}{|c|}{$\begin{array}{l}\text { Notes: Environmental variables were included in X matrices, (Env. Var) with the codes: LCC live coral cover, RSC sponge, FMA } \\
\text { fleshy macroalgae, SAL salinity and \% TA percentage of sandy texture, n.s. not statistically significant }(P>0.05)\end{array}$} \\
\hline \multicolumn{8}{|c|}{$\begin{array}{l}\text { The }[a+b+c] \text { fraction }=\mathrm{Y} \text { vs. } \mathrm{X} \text { and } \mathrm{W} ;[\mathrm{a}+\mathrm{b}]=\mathrm{Y} \text { vs. } \mathrm{X} ;[\mathrm{b}+\mathrm{c}]=\mathrm{Y} \text { vs. W; }[\mathrm{a}]=\text { pure environmental variation; }[\mathrm{b}]=\text { spatially- } \\
\text { structured environmental variation; }[\mathrm{c}]=\text { pure spatial variation; and }[\mathrm{d}]=\text { unexplained variation. Total Exp. Total explained variation } \\
{[\mathrm{a}+\mathrm{b}+\mathrm{c}]}\end{array}$} \\
\hline
\end{tabular}


This study found that the bacterial assemblage at local level was different between the mucus and tissue of the corals studied, as well as between the samples of sediment and sea water. This supports the theory that the corals have a different microbiota between their compartments and the surrounding environment (Kvennefors et al. 2010, Krediet et al. 2013). It was shown that the composition of dominant bacteria in both coral species differed to that of the sea water, which had previously been observed in P. damicornis (Bourne \& Munn 2005). It is thought that some members of the bacterial assemblage of the sea water act as seeds of the coral microbiota, such that these may acquire certain specific bacteria from the environment without vertical transmission (Sunagawa et al. 2010). In this way, the bacteria of the coral mucus could be acquired from the surrounding sea water (Guppy \& Bythell 2006), or indeed by re-suspension of benthic sediments (Sweet et al. 2011). It has also been suggested that the coral mucus is constituted by transitory bacteria that originate from other environmental sources, causing the mucus to present similar ribotypes to those of the sea water and sediment (Bourne \& Webster 2013).

No significant similarity was found between the bacteria of the coral and of the sediments, although the bacteria present in the sediments could colonize the coral surfaces (Schöttner $e t$ al. 2013). The sediments could serve as a reservoir of opportunistic pathogenic agents that can generate diseases and mortality in the corals. For this reason, study of the bacterial assemblages associated with the sediments in coral reefs contributes to the understanding of the synergy between the bacteria of the sediment and those of the corals (Carlos et al. 2013), particularly when changes are evaluated in bacterial composition in the corals (Guppy \& Bythell 2006). It has been documented that the resident bacteria of the coral compete for nutrients and ecological niches with other invasive microbial in the mucus and tissue (Littman et al. 2009). It is considered that specific invertebrate-microbial associations play an important role in the maintenance of healthy coral and protect it from invasion by pathogenic microbes (Li et al. 2014). For this reason, changes in bacterial consortia can predict the appearance of signs of disease and can be used as indicators of coral reef health (Bourne \& Webster 2013).

Other studies have shown that the bacterial assemblages associated with the corals present spatio-temporal variations (Lee et al. 2012, Krediet et al. 2013). However, the spatial analysis indicated that the sites of Nayarit and Jalisco did not differ in terms of bacterial composition and presented specificity despite the geographic distance. In the sites of Colima, the dominant groups of bacteria differed from those of the other sites. Furthermore, the bacterial composition of the sea water and sediments differentiates in a north-south latitudinal gradient
(Nayarit, Jalisco and Colima). This coincides with the changes observed in the bacterial assemblages of Orbicella (formerly Montastraea) and P. astreoides in sites in the Caribbean (Morrow et al. 2012). In Acropora and Porites of the Mexican Caribbean and Indonesia, McKew et al. (2012) demonstrated an important spatial variation in the assemblages of geographically different sites, but did not find differences between the species and the surrounding sea water. Similarly, Littman et al. (2009) reported that the assemblages associated with $A$. millepora in the GBR were grouped according to the geographic location of the sites and were not associated with coral species. This indicates that the dominant bacteria differ among geographically distant corals. Furthermore, it was observed that the bacterial assemblage was stable in summer and winter, suggesting that this was due to fluctuations in temperature of $<10^{\circ} \mathrm{C}$. In contrast, the assemblage associated with colonies of Oculina patagonica in the Mediterranean Sea varied between summer and winter because of the larger changes in temperature that occur in this area $\left(>20^{\circ} \mathrm{C}\right.$ ) (Koren \& Rosenberg 2006). In this study, the NMDS and ANOSIM based on DGGE profiles suggest that there is no important temporal variation in the bacterial assemblages among the coral species and substrates studied. However, it is necessary to consider that the fluctuations of temperature between summer and winter in the study area were less than $5^{\circ} \mathrm{C}$, which could explain such 'stability' in both seasons. Previous studies suggest that the bacterial assemblages of healthy coral soften respond to seasonal fluctuations (Koren \& Rosenberg 2006).

Different studies have explored the effects of environmental parameters on the density, diversity and microbial composition of coral ecosystems (Lee et al. 2012, Kelly et al. 2014, Li et al. 2014). For example, Bourne et al. (2008) correlated the presence of Vibrio spp. with increased temperatures and decreased density of zooxantellae of $A$. millepora during a bleaching event on Magnetic Island (GBR). All of this supports the hypothesis that 'everything is everywhere, but the environment selects' (Baas-Becking 1934). Nevertheless, Guppy \& Bythell (2006), using DGGE profiles, did not find a correlation between the structure of the bacterial assemblage associated with the mucus of $O$. faveolata and variables considered representative of sea water quality.

In the sediments, changes in bacterial composition were correlated with the coverage of macroalgae, sponges and live coral. The high coverages of fleshy macroalgae have a negative effect on the health of the coral reefs since they generate abrasion and produce a shade effect on the coral tissues (McCook et al. 2001). Likewise, they cause elevated levels of dissolved organic carbon (DOC) due to the excess of photosynthates they release in the water column. This acts to 
alter the equilibrium between the corals and their associated microbiota and accelerates the growth of coral mucus bacteria (Ceh et al. 2011). Kelly et al. (2014) indicate that sites with higher coverages of fleshy macroalgae present a high abundance of Gammaproteobacteria (Enterobacterial and Pseudomonadal), while a greater abundance of Alphaproteobacteria is associated with sites with higher live coral cover. In this sense, evidence is provided by the fact that Carrizales and Punto B present the highest coverage of fleshy macroalgae and direct supply of nutrients through rainwater runoff compared to the rest of the sites (apart from Costa Fragata Somero) (Appendix B, Table B4). This could explain the difference between the bacterial assemblages of these sites and those of the other studied sites.

The bacterial assemblage associated with the sponges is dynamic and, as with the corals, is interconnected with that of the sea water and sediments, suggesting that the bacterial microbiota of corals in sites with high coverage of sponges is possibly influenced by this condition (Webster \& Taylor 2012). In this sense, and despite the fact that the sites Carrizales and Punto B in Colima differed from the other sites, the greatest coverage of sponges was recorded only in the site Punto B and it is probable that this can explain why the bacterial assemblage of Punto B differed among substrates and sites.

Li et al. (2014) observed that rainfall and dissolved oxygen were the environmental parameters that most influenced the variation of the bacterial assemblage of the mucus, tissue and skeleton of $P$. lutea in the Luhuitou reef, in northern China. Chen et al. (2011) found that rain was the factor most correlated with the bacterial assemblage of Isopora palifera in Tan-Tzei Bay southeast of Taiwan. The observed influence of rainfall supports the notion that some bacteria of the coral could be derived from terrestrial soils. However, in this study, no correlation was found between the quantity of dissolved oxygen (data not presented) and variation in bacterial groups. Moreover, the influence of rainfall and its effect on the runoff of continental water riverine influx were not evaluated.

This study represents the first effort made to understand the structure and spatio-temporal variation of the bacterial assemblages in the two most abundant coral species in the Mexican Central Pacific. It was determined that the corals $P$. damicornis and P. verrucosa have a specificity of dominant bacteria, which are in most cases maintained despite geographic distance and temporal variation. The bacteria vary in the compartments of the holobiont and environmental variables, such as coverage of live coral, macroalgae and sponges; play a significant role in the variation of the composition of dominant bacteria in corals, sea water and sediments. In order to further understand the magnitude of the change in structure and dynamics of the bacterial assemblages in the corals of the Mexican Central Pacific and their potential relationship with the health of the reef ecosystem, future studies could employ metagenomic techniques that allow estimation of the less abundant OTUs, the 'Rare Biosphere'.

\section{ACKNOWLEDGEMENTS}

We are grateful with Amílcar L. Cupul-Magaña who helped us during field sampling, and also providing some benthic data bases. Pablo Morales and Camila Fernández-Saez from the Laboratory of Environmental Microbiology in the University of Antofagasta for their advice in conducting the fingerprint profiling analyses. This work was partially funded by Universidad de Guadalajara (P3E2010-2015 to F.A. Rodríguez-Zaragoza), PROMEP (103.5/08/2919 and 103.5/10/927 to F.A. Rodríguez-Zaragoza), CONABIO (HJ026 to L.E. CalderónAguilera), (PIFI-2010-14MSU0010Z-10 to A. L. CupulMagaña), as well as the authorities from Isla Isabel and Islas Marietas National Park. Finally J. Hernández-Zulueta acknowledges the doctoral fellowship from CONACYT (0262538).

\section{LITERATURE CITED}

Ausubel FM. 2002. Short protocols in molecular biology: A compendium of methods from current protocols in molecular biology, 1512 pp. John Wiley \& Sons, New York.

Baas-Becking LGM. 1934. Geobiologie of inleiding tot de milieukunde (in Dutch). Van Stockkum \& Zoon, The Hague, Netherlands

Ban SS, NAJ Graham \& SR Connolly. 2014. Evidence for multiple stressor interactions and effects on coral reefs. Global Change Biology 20: 681-697.

Bourne DG \& CB Munn. 2005. Diversity of bacteria associated with the coral Pocillopora damicornis from the Great Barrier Reef. Environmental Microbiology 7: 11621174.

Bourne DG \& NS Webster. 2013. Coral reef bacterial communities. In: Rosenberg E, EF DeLong, S Lory, E Stackebrandt \& F Thompson (eds). The Prokariotes, pp. 163187. Springer-Verlag, Heidelberg.

Bourne D, Y Iida, S Uthicke \& C Smith-Keune. 2008. Changes in coral-associated microbial communities during a bleaching event. International Society for Microbial Ecology Journal 2: 350-363.

Buoyocoz GJ. 1928. The hydrometer method for studying soils. Soil Science 25: 365-369.

Carlos C, TT Torres \& LMM Ottoboni. 2013. Bacterial communities and species-specific associations with the mucus of Brazilian coral species. Scientific Reports 3: 1624.

Ceh J, M van Keulen \& DG Bourne. 2011. Coral-associated bacterial communities on Ningaloo Reef, Western Australia. FEMS Microbiology Ecology 75: 134-144. 
Chen CP, CH Tseng, CA Chen \& SL Tang. 2011. The dynamics of microbial partnerships in the coral Isopora palifera. International Society for Microbial Ecology Journal 5: 728-740.

Clarke KR \& RN Gorley. 2006. PRIMER v6: User manual/ tutorial, 192 pp. PRIMER-E, Plymouth.

Ferris MJ, G Muyzer \& DM Ward. 1996. Denaturing gradient gel electrophoresis profiles of $16 \mathrm{~S}$ rRNA-defined populations inhabiting a hot spring microbial mat community. Applied and Environmental Microbiology 62: 340-346.

Grimont F \& PAD Grimont. 1986. Ribosomal ribonucleic acid gene restriction patterns as potential taxonomic tools. Annales de l'Institut Pasteur. Microbiology 137B: 165-175.

Guppy R \& JC Bythell. 2006. Environmental effects on bacterial diversity in the surface mucus layer of the reef coral Montastraea faveolata. Marine Ecology Progress Series 137: 133-142.

Kelly LW, GJ Williams, KL Barott, CA Carlson, DA Dinsdale, RA Edwards, AF Haas, M Haynes, YW Lima, T McDole, CE Nelson, E Sala, SA Sandin, JE Smith, MJA Vermeijg, M Youlei \& F Rohwer. 2014. Local genomic adaptation of coral reef-associated microbiomes to gradients of natural variability and anthropogenic stressors. Proceedings of the National Academy of Sciences of the United States of America 111: 10227-10232.

Koren O \& E Rosenberg. 2006. Bacteria associated with mucus and tissues of the coral Oculina patagonica in summer and winter. Applied and Environmental Microbiology 72: 5254-5259.

Krediet CJ, KB Ritchie, VJ Paul \& M Teplitski. 2013. Coral-associated microorganisms and their roles in promoting coral health and thwarting diseases. Proceedings of the Royal Society of London B. Biological Sciences 280: 2012-2328.

Kvennefors E, E Sampayo, T Ridgway, A Barnes \& C Hoegh-Guldberg. 2010. Bacterial communities of two ubiquitous Great Barrier Reef Corals reveals both site and species-specificity of common bacterial associates. PLoS One 5(4): e10401. <https://doi.org/10.1371/journal.pone. 0010401>

Lee OO, J Yang, S Bougouffa, Y Wang, Z Batang, R Tian, A Al-Suwailem \& PY Qian. 2012. Spatial and species variations in bacterial communities associated with corals from the Red Sea as revealed by pyrosequencing. Applied and Environmental Microbiology 78: 7173-7184.

Legendre P \& L Legendre. 1998. Numerical ecology, 853 pp. Elsevier Science BV, Amsterdam

Li J, Q Chen, LJ Long, JD Dong, J Yang \& S Zhang. 2014. Bacterial dynamics within the mucus, tissue and skeleton of the coral Porites lutea during different seasons. Scientific Reports 4: 7320.

Littman RA, BL Willis, C Pfeffer \& DG Bourne. 2009. Diversity of coral-associated bacteria differs with location, but not species for three acroporids on the Great Barrier Reef. FEMS Microbiology Ecology 68: 152-163.
McCook LJ, J Jompa \& G Díaz-Pulido. 2001. Competition between corals and algae on coral reefs: a review of evidence and mechanisms. Coral Reefs 19: 400-417.

McKew BA, AJ Dumbrell, SD Daud, L Hepburn, E Thorpe, L Mogensen \& C Whitby. 2012. Characterization of geographically distinct bacterial communities associated with coral mucus produced by Acropora spp. and Porites spp. Applied and Environmental Microbiology 78: 5229-5237.

Morrow KM, AG Moss, NE Chadwick \& MR Liles. 2012. Bacterial associates of two Caribbean coral species reveal species specific distribution and geographic variability. Applied and Environmental Microbiology 78: 6438-6449.

Mouchka ME, I Hewson \& CD Harvell. 2010. Coralassociated bacterial assemblages: current knowledge and the potential for climate-driven impacts. Integrative and Comparative Biology 50: 662-674.

Muyzer G, EC Dewaal \& AG Uitterlinden. 1993. Profiling of complex microbial populations by denaturing gradient gel electrophoresis analysis of polymerase chain reactionamplified genes coding for $16 \mathrm{~S}$ rRNA. Applied and Environmental Microbiology 59: 695-700.

Reshef L, O Koren, Y Loya, I Zilber-Rosenberg \& E Rosenberg. 2006. The coral probiotic hypothesis. Environmental Microbiology 8: 2067-2073.

Rodríguez-Lanetty M, C Granados-Cifuentes, A Barberan, AJ Bellantuono \& C Bastidas. 2013. Ecological inferences from a deep screening of the complex bacterial consortia associated with the coral, Porites astreoides. Molecular Ecology 22: 4349-4362.

Schöttner S, F Hoffmann, P Cárdenas, HT Rapp, A Boetius \& A Ramette. 2013. Relationships between host phylogeny, host type and bacterial community diversity in cold-water coral reef sponges. PLoS One 8(2): e55505. <https://doi.org/ 10.1371/journal.pone.0055505>

Sunagawa S, CM Woodley \& M Medina. 2010. Threatened corals provide underexplored microbial habitats. PLoS One 5(3): e9554. <https://doi.org/10.1371/journal.pone.0009554>

Sweet MJ, A Croquer \& JC Bythell. 2011. Bacterial assemblages differ between compartments within the coral holobiont. Coral Reefs 30: 39-52.

Ter-Braak CJF \& P Smilauer. 2002. CANOCO reference manual and CanoDraw for Windows user's guide: software for canonical community ordination (version 4.5), $500 \mathrm{pp}$. Microcomputer Power, Ithaca.

Warneke S, M Arenskotter, KB Tenberge \& A Steinbuchel. 2007. Bacterial degradation of poly (trans-1, 4-isoprene) (guttapercha). Microbiology 153: 347-356.

Webster NS \& MW Taylor. 2012. Marine sponges and their microbial symbionts: love and other relationships. Environmental Microbiology 14: 335-346.

Wyrtki K. 1966. Oceanography of the eastern equatorial Pacific Ocean. Oceanography and Marine Biology: An Annual Review 4: 33-68. 


\section{APPENDix A}

Table A1. Number of bacterial OTUs (bands) present in the tissue and mucus P. damicornis and P. verrucosa, sea water and sediment. Code: CFS: Costa Fragata Somero; ZR: Zona de Restauración; P: Pelícanos; CU: Cuastecomatito; CRZ: Carrizales and PB: Punto B / Número de OTUs bacterianos (bandas) presentes en el tejido y mucus P. damicornis y P. verrucosa, agua de mar y sedimento. Códigos: CFS: Costa Fragata Somero; ZR: Área de Restauración; P: Pelícanos; CU: Cuastecomatito; CRZ: Carrizales y PB: Punto B

\begin{tabular}{|c|c|c|c|c|c|c|c|c|c|c|c|c|c|c|c|c|c|c|c|c|c|c|c|}
\hline \multirow{2}{*}{ Substrates } & \multirow{2}{*}{ Sites } & \multirow{2}{*}{ Season } & \multicolumn{20}{|c|}{ Bands } & \multirow[b]{2}{*}{ Total } \\
\hline & & & 1 & 2 & 3 & 4 & 5 & 6 & 7 & 8 & 9 & 10 & 11 & 12 & 13 & 14 & 15 & 16 & 17 & 18 & 19 & 20 & \\
\hline Tissue & CFS & Summer & 1 & 0 & 1 & 1 & 1 & 1 & 0 & 1 & 1 & 1 & 1 & 1 & 0 & 1 & 1 & 0 & 0 & 0 & 0 & 0 & 12 \\
\hline \multirow[t]{11}{*}{ P. damicornis } & ZR & & 1 & 0 & 1 & 1 & 1 & 1 & 0 & 1 & 1 & 1 & 1 & 1 & 0 & 1 & 1 & 0 & 0 & 0 & 0 & 0 & 12 \\
\hline & $\mathrm{P}$ & & 1 & 0 & 1 & 1 & 1 & 1 & 0 & 1 & 1 & 1 & 1 & 1 & 0 & 1 & 1 & 0 & 0 & 0 & 0 & 0 & 12 \\
\hline & $\mathrm{CU}$ & & 1 & 0 & 1 & 1 & 1 & 1 & 0 & 1 & 1 & 1 & 1 & 1 & 0 & 1 & 1 & 0 & 0 & 0 & 0 & 0 & 12 \\
\hline & CRZ & & 1 & 0 & 1 & 1 & 1 & 1 & 0 & 1 & 0 & 1 & 1 & 0 & 1 & 1 & 0 & 0 & 0 & 0 & 0 & 0 & 10 \\
\hline & PB & & 1 & 0 & 1 & 1 & 1 & 1 & 0 & 1 & 0 & 1 & 1 & 0 & 1 & 1 & 0 & 0 & 0 & 0 & 0 & 0 & 10 \\
\hline & CFS & Winter & 1 & 0 & 1 & 1 & 1 & 1 & 0 & 1 & 1 & 1 & 1 & 1 & 0 & 1 & 1 & 0 & 0 & 0 & 0 & 0 & 12 \\
\hline & $\mathrm{ZR}$ & & 1 & 0 & 1 & 1 & 1 & 1 & 0 & 1 & 1 & 1 & 1 & 1 & 0 & 1 & 1 & 0 & 0 & 0 & 0 & 0 & 12 \\
\hline & $\mathrm{P}$ & & 1 & 0 & 1 & 1 & 1 & 1 & 0 & 1 & 1 & 1 & 1 & 1 & 0 & 1 & 1 & 0 & 0 & 0 & 0 & 0 & 12 \\
\hline & $\mathrm{CU}$ & & 1 & 0 & 1 & 1 & 1 & 1 & 0 & 1 & 1 & 1 & 1 & 1 & 0 & 1 & 1 & 0 & 0 & 0 & 0 & 0 & 12 \\
\hline & CRZ & & 1 & 0 & 1 & 1 & 1 & 1 & 0 & 1 & 0 & 1 & 1 & 0 & 1 & 1 & 0 & 0 & 0 & 0 & 0 & 0 & 10 \\
\hline & PB & & 1 & 0 & 1 & 1 & 1 & 1 & 0 & 1 & 0 & 1 & 1 & 0 & 1 & 1 & 0 & 0 & 0 & 0 & 0 & 0 & 10 \\
\hline Tissue & CFS & Summer & 1 & 1 & 1 & 1 & 0 & 0 & 1 & 1 & 0 & 1 & 1 & 0 & 1 & 0 & 0 & 0 & 0 & 0 & 0 & 0 & 9 \\
\hline \multirow[t]{11}{*}{ P. verrucosa } & ZR & & 1 & 1 & 1 & 1 & 0 & 0 & 1 & 1 & 0 & 1 & 1 & 0 & 1 & 0 & 0 & 0 & 0 & 0 & 0 & 0 & 9 \\
\hline & $\mathrm{P}$ & & 1 & 1 & 1 & 1 & 0 & 0 & 1 & 1 & 0 & 1 & 1 & 0 & 1 & 0 & 0 & 0 & 0 & 0 & 0 & 0 & 9 \\
\hline & $\mathrm{CU}$ & & 1 & 1 & 1 & 1 & 0 & 0 & 1 & 1 & 0 & 1 & 1 & 0 & 1 & 0 & 0 & 0 & 0 & 0 & 0 & 0 & 9 \\
\hline & CRZ & & 1 & 1 & 1 & 1 & 0 & 0 & 1 & 1 & 0 & 1 & 1 & 1 & 0 & 0 & 0 & 0 & 0 & 0 & 0 & 0 & 9 \\
\hline & $\mathrm{PB}$ & & 1 & 1 & 0 & 0 & 0 & 0 & 1 & 1 & 0 & 1 & 1 & 1 & 1 & 1 & 0 & 0 & 0 & 0 & 0 & 0 & 9 \\
\hline & CFS & Winter & 1 & 1 & 1 & 1 & 0 & 0 & 1 & 1 & 0 & 1 & 1 & 0 & 1 & 0 & 0 & 0 & 0 & 0 & 0 & 0 & 9 \\
\hline & ZR & & 1 & 1 & 1 & 1 & 0 & 0 & 1 & 1 & 0 & 1 & 1 & 0 & 1 & 0 & 0 & 0 & 0 & 0 & 0 & 0 & 9 \\
\hline & $\mathrm{P}$ & & 1 & 1 & 1 & 1 & 0 & 0 & 1 & 1 & 0 & 1 & 1 & 0 & 1 & 0 & 0 & 0 & 0 & 0 & 0 & 0 & 9 \\
\hline & $\mathrm{CU}$ & & 1 & 1 & 1 & 1 & 0 & 0 & 1 & 1 & 0 & 1 & 1 & 0 & 1 & 0 & 0 & 0 & 0 & 0 & 0 & 0 & 9 \\
\hline & CRZ & & 1 & 1 & 1 & 1 & 0 & 0 & 1 & 1 & 0 & 1 & 1 & 1 & 0 & 0 & 0 & 0 & 0 & 0 & 0 & 0 & 9 \\
\hline & PB & & 1 & 1 & 0 & 0 & 0 & 0 & 1 & 1 & 0 & 1 & 1 & 1 & 1 & 1 & 0 & 0 & 0 & 0 & 0 & 0 & 9 \\
\hline Mucus & CFS & Summer & 1 & 1 & 1 & 1 & 1 & 1 & 1 & 1 & 1 & 1 & 0 & 0 & 0 & 0 & 0 & 0 & 0 & 0 & 0 & 0 & 10 \\
\hline \multirow[t]{11}{*}{ P. damicornis } & $\mathrm{ZR}$ & & 1 & 1 & 1 & 1 & 1 & 1 & 1 & 1 & 1 & 1 & 0 & 0 & 0 & 0 & 0 & 0 & 0 & 0 & 0 & 0 & 10 \\
\hline & $\mathrm{P}$ & & 1 & 0 & 1 & 1 & 1 & 1 & 1 & 0 & 1 & 1 & 1 & 1 & 0 & 1 & 1 & 0 & 0 & 0 & 0 & 0 & 12 \\
\hline & $\mathrm{CU}$ & & 1 & 0 & 1 & 1 & 1 & 1 & 1 & 0 & 1 & 1 & 1 & 1 & 0 & 1 & 1 & 0 & 0 & 0 & 0 & 0 & 12 \\
\hline & CRZ & & 1 & 1 & 1 & 0 & 1 & 1 & 1 & 0 & 0 & 1 & 1 & 1 & 0 & 0 & 0 & 0 & 0 & 0 & 0 & 0 & 9 \\
\hline & PB & & 1 & 1 & 1 & 0 & 1 & 1 & 1 & 0 & 1 & 1 & 1 & 1 & 1 & 0 & 0 & 0 & 0 & 0 & 0 & 0 & 11 \\
\hline & CFS & Winter & 1 & 1 & 1 & 1 & 1 & 1 & 1 & 1 & 1 & 1 & 0 & 0 & 0 & 0 & 0 & 0 & 0 & 0 & 0 & 0 & 10 \\
\hline & ZR & & 1 & 1 & 1 & 1 & 1 & 1 & 1 & 1 & 1 & 1 & 0 & 0 & 0 & 0 & 0 & 0 & 0 & 0 & 0 & 0 & 10 \\
\hline & $\mathrm{P}$ & & 1 & 0 & 1 & 1 & 1 & 1 & 1 & 0 & 1 & 1 & 1 & 1 & 0 & 1 & 1 & 0 & 0 & 0 & 0 & 0 & 12 \\
\hline & $\mathrm{CU}$ & & 1 & 0 & 1 & 1 & 1 & 1 & 1 & 0 & 1 & 1 & 1 & 1 & 0 & 1 & 1 & 0 & 0 & 0 & 0 & 0 & 12 \\
\hline & CRZ & & 1 & 1 & 1 & 0 & 1 & 1 & 1 & 0 & 0 & 1 & 1 & 1 & 0 & 0 & 0 & 0 & 0 & 0 & 0 & 0 & 9 \\
\hline & PB & & 1 & 1 & 1 & 0 & 1 & 1 & 1 & 0 & 1 & 1 & 1 & 1 & 1 & 0 & 0 & 0 & 0 & 0 & 0 & 0 & 11 \\
\hline
\end{tabular}


Table A1 continued. Number of bacterial OTUs (bands) present in the tissue and mucus P. damicornis and P. verrucosa, sea water and sediment. Code: CFS: Costa Fragata Somero; ZR: Zona de Restauración; P: Pelícanos; CU: Cuastecomatito; CRZ: Carrizales and PB: Punto B / Número de OTUs bacterianos (bandas) presentes en el tejido y mucus P. damicornis y P. verrucosa, agua de mar y sedimento. Códigos: CFS: Costa Fragata Somero; ZR: Área de Restauración; P: Pelícanos; CU: Cuastecomatito; CRZ: Carrizales y PB: Punto B

\begin{tabular}{|c|c|c|c|c|c|c|c|c|c|c|c|c|c|c|c|c|c|c|c|c|c|c|c|}
\hline \multirow[t]{2}{*}{ Substrates } & \multirow[t]{2}{*}{ Sites } & \multirow[t]{2}{*}{ Season } & \multicolumn{21}{|c|}{ Bands } \\
\hline & & & 1 & 2 & 3 & 4 & 5 & 6 & 7 & 8 & 9 & 10 & 11 & 12 & 13 & 14 & 15 & 16 & 17 & 18 & 19 & 20 & Tota \\
\hline Mucus & CFS & Summer & 1 & 1 & 1 & 0 & 1 & 1 & 0 & 1 & 0 & 1 & 1 & 0 & 1 & 0 & 0 & 0 & 0 & 0 & 0 & 0 & 9 \\
\hline \multirow[t]{11}{*}{ P. verrucosa } & ZR & & 1 & 1 & 1 & 0 & 1 & 1 & 0 & 1 & 0 & 1 & 1 & 0 & 1 & 0 & 0 & 0 & 0 & 0 & 0 & 0 & 9 \\
\hline & $\mathrm{P}$ & & 1 & 1 & 1 & 0 & 1 & 1 & 0 & 1 & 0 & 1 & 1 & 0 & 1 & 0 & 0 & 0 & 0 & 0 & 0 & 0 & 9 \\
\hline & $\mathrm{CU}$ & & 1 & 1 & 1 & 0 & 1 & 1 & 0 & 1 & 0 & 1 & 1 & 0 & 1 & 0 & 0 & 0 & 0 & 0 & 0 & 0 & 9 \\
\hline & CRZ & & 1 & 0 & 1 & 0 & 1 & 1 & 0 & 1 & 1 & 1 & 1 & 0 & 1 & 1 & 0 & 0 & 0 & 0 & 0 & 0 & 10 \\
\hline & PB & & 1 & 0 & 1 & 0 & 1 & 1 & 0 & 1 & 1 & 1 & 1 & 0 & 1 & 1 & 0 & 0 & 0 & 0 & 0 & 0 & 10 \\
\hline & CFS & Winter & 1 & 1 & 1 & 0 & 1 & 1 & 0 & 1 & 0 & 1 & 1 & 0 & 1 & 0 & 0 & 0 & 0 & 0 & 0 & 0 & 9 \\
\hline & ZR & & 1 & 1 & 1 & 0 & 1 & 1 & 0 & 1 & 0 & 1 & 1 & 0 & 1 & 0 & 0 & 0 & 0 & 0 & 0 & 0 & 9 \\
\hline & $\mathrm{P}$ & & 1 & 1 & 1 & 0 & 1 & 1 & 0 & 1 & 0 & 1 & 1 & 0 & 1 & 0 & 0 & 0 & 0 & 0 & 0 & 0 & 9 \\
\hline & $\mathrm{CU}$ & & 1 & 1 & 1 & 0 & 1 & 1 & 0 & 1 & 0 & 1 & 1 & 0 & 1 & 0 & 0 & 0 & 0 & 0 & 0 & 0 & 9 \\
\hline & CRZ & & 1 & 0 & 1 & 0 & 1 & 1 & 0 & 1 & 1 & 1 & 1 & 0 & 1 & 1 & 0 & 0 & 0 & 0 & 0 & 0 & 10 \\
\hline & PB & & 1 & 0 & 1 & 0 & 1 & 1 & 0 & 1 & 1 & 1 & 1 & 0 & 1 & 1 & 0 & 0 & 0 & 0 & 0 & 0 & 10 \\
\hline \multirow[t]{12}{*}{ Sea water } & CFS & Summer & 1 & 0 & 1 & 0 & 1 & 1 & 0 & 1 & 1 & 0 & 1 & 0 & 0 & 0 & 0 & 0 & 0 & 0 & 0 & 0 & 7 \\
\hline & ZR & & 1 & 0 & 1 & 0 & 1 & 1 & 0 & 1 & 1 & 0 & 1 & 0 & 0 & 0 & 0 & 0 & 0 & 0 & 0 & 0 & 7 \\
\hline & $\mathrm{P}$ & & 0 & 0 & 1 & 1 & 0 & 1 & 0 & 1 & 1 & 0 & 1 & 1 & 0 & 0 & 1 & 0 & 0 & 0 & 0 & 0 & 8 \\
\hline & $\mathrm{CU}$ & & 0 & 0 & 1 & 1 & 0 & 1 & 0 & 1 & 1 & 0 & 1 & 1 & 0 & 0 & 1 & 0 & 0 & 0 & 0 & 0 & 8 \\
\hline & CRZ & & 1 & 0 & 1 & 1 & 1 & 0 & 0 & 1 & 1 & 0 & 0 & 1 & 1 & 0 & 0 & 0 & 1 & 0 & 0 & 0 & 9 \\
\hline & PB & & 1 & 0 & 1 & 1 & 1 & 0 & 0 & 1 & 1 & 0 & 0 & 1 & 1 & 0 & 0 & 0 & 1 & 0 & 0 & 0 & 9 \\
\hline & CFS & Winter & 1 & 0 & 1 & 0 & 1 & 1 & 0 & 1 & 1 & 0 & 1 & 0 & 0 & 0 & 0 & 0 & 0 & 0 & 0 & 0 & 7 \\
\hline & ZR & & 1 & 0 & 1 & 0 & 1 & 1 & 0 & 1 & 1 & 0 & 1 & 0 & 0 & 0 & 0 & 0 & 0 & 0 & 0 & 0 & 7 \\
\hline & $\mathrm{P}$ & & 0 & 0 & 1 & 1 & 0 & 1 & 0 & 1 & 1 & 0 & 1 & 1 & 0 & 0 & 1 & 0 & 0 & 0 & 0 & 0 & 8 \\
\hline & $\mathrm{CU}$ & & 0 & 0 & 1 & 1 & 0 & 1 & 0 & 1 & 1 & 0 & 1 & 1 & 0 & 0 & 1 & 0 & 0 & 0 & 0 & 0 & 8 \\
\hline & CRZ & & 1 & 0 & 1 & 1 & 1 & 0 & 0 & 1 & 1 & 0 & 0 & 1 & 1 & 0 & 0 & 0 & 1 & 0 & 0 & 0 & 9 \\
\hline & PB & & 1 & 0 & 1 & 1 & 1 & 0 & 0 & 1 & 1 & 0 & 0 & 1 & 1 & 0 & 0 & 0 & 1 & 0 & 0 & 0 & 9 \\
\hline \multirow[t]{12}{*}{ Sediment } & CFS & Summer & 1 & 1 & 0 & 1 & 1 & 0 & 1 & 1 & 1 & 0 & 1 & 0 & 1 & 1 & 1 & 0 & 1 & 1 & 0 & 0 & 13 \\
\hline & ZR & & 1 & 1 & 0 & 1 & 1 & 0 & 1 & 1 & 1 & 0 & 1 & 0 & 1 & 1 & 1 & 0 & 1 & 1 & 0 & 0 & 13 \\
\hline & $\mathrm{P}$ & & 0 & 0 & 0 & 1 & 1 & 0 & 1 & 1 & 1 & 1 & 0 & 1 & 1 & 0 & 1 & 0 & 1 & 1 & 0 & 0 & 11 \\
\hline & $\mathrm{CU}$ & & 0 & 0 & 0 & 1 & 1 & 0 & 1 & 1 & 1 & 1 & 0 & 1 & 1 & 0 & 1 & 0 & 1 & 1 & 0 & 0 & 11 \\
\hline & CRZ & & 0 & 0 & 0 & 0 & 0 & 1 & 1 & 1 & 1 & 0 & 1 & 1 & 1 & 1 & 0 & 1 & 1 & 1 & 0 & 0 & 11 \\
\hline & PB & & 0 & 0 & 0 & 0 & 0 & 1 & 1 & 1 & 1 & 0 & 1 & 1 & 1 & 1 & 0 & 1 & 0 & 0 & 0 & 0 & 9 \\
\hline & CFS & Winter & 1 & 1 & 0 & 1 & 1 & 0 & 1 & 1 & 1 & 0 & 1 & 0 & 1 & 1 & 1 & 0 & 1 & 1 & 0 & 0 & 13 \\
\hline & ZR & & 1 & 1 & 0 & 1 & 1 & 0 & 1 & 1 & 1 & 0 & 1 & 0 & 1 & 1 & 1 & 0 & 1 & 1 & 0 & 0 & 13 \\
\hline & $\mathrm{P}$ & & 0 & 0 & 0 & 1 & 1 & 0 & 1 & 1 & 1 & 1 & 0 & 1 & 1 & 0 & 1 & 0 & 1 & 1 & 1 & 1 & 13 \\
\hline & $\mathrm{CU}$ & & 0 & 0 & 0 & 1 & 1 & 0 & 1 & 1 & 1 & 1 & 0 & 1 & 1 & 0 & 1 & 0 & 1 & 1 & 0 & 0 & 11 \\
\hline & CRZ & & 0 & 0 & 0 & 0 & 0 & 1 & 1 & 1 & 1 & 0 & 1 & 1 & 1 & 1 & 0 & 1 & 1 & 1 & 0 & 0 & 11 \\
\hline & PB & & 0 & 0 & 0 & 0 & 0 & 1 & 1 & 1 & 1 & 0 & 1 & 1 & 1 & 1 & 0 & 1 & 0 & 0 & 0 & 0 & 9 \\
\hline
\end{tabular}




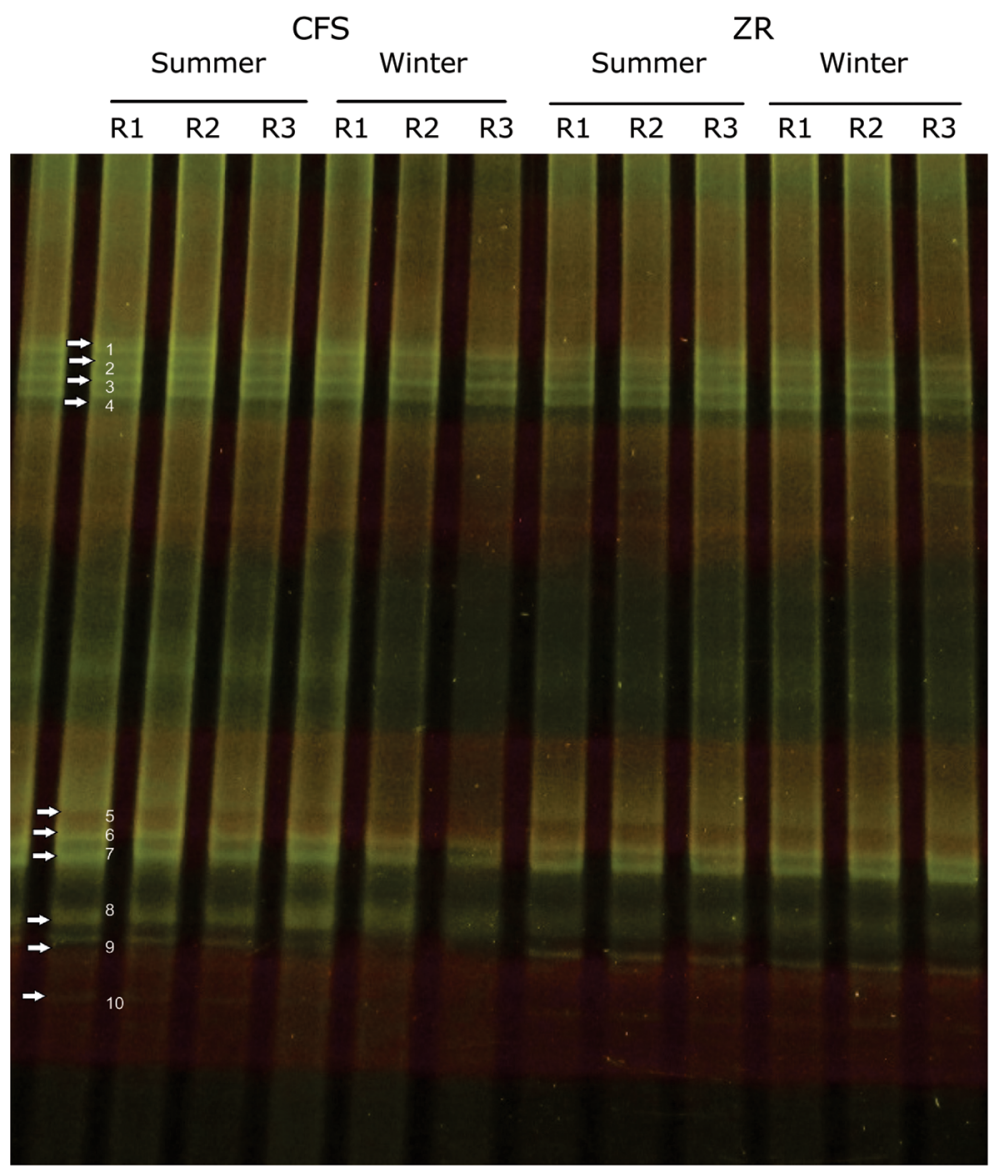

Figure A1. DGGE of PCR-amplified 165 rDNA fragments of Pocillopora damicornis mucus in summer and winter. Code: CFS: Costa Fragata Somero; ZR: Zona de Restauración; R1: Replica 1, R2: Replica 2 and R3: Replica 3. The arrows indicate the band number / Visualización de geles de DGGE a partir de fragmentos del ADNr $16 \mathrm{~S}$ del mucus de P. damicornis colectadas en verano e invierno. Códigos: CFS: Costa Fragata Somero; ZR: Zona de Restauración; R1: Réplica 1, R2: Réplica 2 y R3: Réplica 3. Las fechas indican el número de banda 


\section{APPENDIX B}

Table B1. One-way similarity analysis (ANOSIM), results from comparing the bacterial OTUs among Season, Substrates and Sites in the corals reef ecosystem on Mexican Central Pacific. Code: CFS (Costa Fragata Somero), ZR (Zona de Restauración), P (Pelicanos), CU (Cuastecomatito), CRZ (Carrizales) and PB (Punto B). TPd (Tissue of P. damicornis), TPv (Tissue of P. verrucosa), M Pd (M ucus of P. damicornis), M Pv (M ucus of P. verrucosa), SW (Sea water) and Sdmt (Sediment) / Resultados del análisis de similitudes (ANOSIM) para comparar los OTUs bacterianos entre la Estación, Sustratos y los Sitios en los ecosistemas de coral del Pacífico central mexicano. Códigos: CFS (Costa Fragata Somero), ZR (Zona de Restauración), P (Pelicanos), CU (Cuastecomatito), CRZ (Carrizales) y PB (Punto B). TPd (Tejido de P. damicornis), TPv (Tejido de P. verrucosa), MPd (Mucus de P. damicornis), MPv (Mucus de P. verrucosa), SW (Agua de mar) y Sdmt (Sedimentos)

\begin{tabular}{|c|c|c|}
\hline & $\frac{\mathrm{R}}{\text { statistic }}$ & $\begin{array}{c}\text { Significance } \\
\text { level }\end{array}$ \\
\hline \multicolumn{3}{|l|}{ Global test } \\
\hline Season & -0.0009 & 0.9850 \\
\hline Substrates & 0.7460 & 0.0001 \\
\hline Sites & 0.6590 & 0.0001 \\
\hline \multicolumn{3}{|c|}{ Pairwise comparisons among Substrates } \\
\hline $\mathrm{TPd} v s \mathrm{TPv}$ & 1 & 0.0001 \\
\hline TPd $v s$ MPd & 1 & 0.0001 \\
\hline $\mathrm{TPd} v s \mathrm{MPv}$ & 1 & 0.0001 \\
\hline TPd $v s \mathrm{SW}$ & 1 & 0.0001 \\
\hline TPd $v s \mathrm{Sdmt}$ & 1 & 0.0001 \\
\hline TPv $v s \mathrm{MPd}$ & 1 & 0.0001 \\
\hline TPv vs MPv & 1 & 0.0001 \\
\hline TPv vs SW & 1 & 0.0001 \\
\hline TPv vs Sdmt & 1 & 0.0001 \\
\hline MPd $v s \mathrm{MPv}$ & 1 & 0.0001 \\
\hline MPd vs SW & 1 & 0.0001 \\
\hline MPd $v s$ Sdmt & 1 & 0.0001 \\
\hline MPv vs SW & 1 & 0.0001 \\
\hline MPv vs Sdmt & 1 & 0.0001 \\
\hline $\mathrm{SW}$ vs Sdmt & 1 & 0.0001 \\
\hline \multicolumn{3}{|c|}{ Pairwise comparisons among Sites } \\
\hline CFS vs ZR & 0 & 0.1 \\
\hline CFS vs $\mathrm{P}$ & 0.333 & 0.0003 \\
\hline CFS vs CU & 0.333 & 0.0001 \\
\hline CFS vs CRZ & 1 & 0.0001 \\
\hline CFS vs PB & 1 & 0.0001 \\
\hline $\mathrm{ZR}$ vs $\mathrm{P}$ & 0.333 & 0.0001 \\
\hline ZR vs CU & 0.333 & 0.0001 \\
\hline ZR vs CRZ & 1 & 0.0001 \\
\hline $\mathrm{ZR}$ vs PB & 1 & 0.0001 \\
\hline $\mathrm{P} v s \mathrm{CU}$ & 0.033 & 0.0185 \\
\hline $\mathrm{P}$ vs CRZ & 1 & 0.0001 \\
\hline $\mathrm{P}$ vs $\mathrm{PB}$ & 1 & 0.0001 \\
\hline CU vs CRZ & 1 & 0.0001 \\
\hline $\mathrm{CU} v s \mathrm{~PB}$ & 1 & 0.0001 \\
\hline $\mathrm{CRZ}$ vs $\mathrm{PB}$ & 0.5 & 0.0001 \\
\hline
\end{tabular}


Table B2. One-way similarity analysis (ANOSIM), results from comparing the bacterial OTUs among Sites per Substrates in the corals reef ecosystem on Mexican Central Pacific. Code: CFS (Costa Fragata Somero), ZR (Zona de Restauración), P (Pelícanos), CU (Cuastecomatito), CRZ (Carrizales) and PB (Punto B) / Resultados del análisis de similitudes (ANOSIM) para comparar los OTUs bacterianos entre los Sitios por Sustratos en los ecosistemas de coral del Pacífico central mexicano. Códigos: CFS (Costa Fragata Somero), ZR (Zona de Restauración), P (Pelícanos), CU (Cuastecomatito), CRZ (Carrizales) y PB (Punto B)

\begin{tabular}{|c|c|c|c|c|c|}
\hline Test & $\begin{array}{c}\mathrm{R} \\
\text { statistic }\end{array}$ & $\begin{array}{c}\text { Significance } \\
\text { level }\end{array}$ & Test & $\begin{array}{c}\mathrm{R} \\
\text { statistic }\end{array}$ & $\begin{array}{l}\text { Significance } \\
\text { level }\end{array}$ \\
\hline Global test & & & Global test & & \\
\hline Tissue of $P$. damicornis & 0.533 & 0.0001 & Mucus of $P$. verrucosa & 0.533 & 0.0001 \\
\hline \multicolumn{3}{|c|}{$\begin{array}{l}\text { Pairwise comparisons tissue of } P \text {. damicornis } \\
\text { among Sites }\end{array}$} & \multicolumn{3}{|c|}{$\begin{array}{l}\text { Pairwise comparisons mucus of } P \text {. verrucosa } \\
\text { among Sites }\end{array}$} \\
\hline CFS vs ZR & 0 & 0.100 & CFS vs ZR & 0 & 0.100 \\
\hline CFS vs $\mathrm{P}$ & 0 & 0.100 & CFS vs $\mathrm{P}$ & 0 & 0.100 \\
\hline $\mathrm{CFS} v s \mathrm{CU}$ & 0 & 0.100 & $\mathrm{CFS}$ vs $\mathrm{CU}$ & 0 & 0.100 \\
\hline CFS vs CRZ & 1 & 0.0002 & CFS vs CRZ & 1 & 0.0002 \\
\hline CFS vs $\mathrm{PB}$ & 1 & 0.0002 & CFS vs PB & 1 & 0.0002 \\
\hline $\mathrm{ZR} v s \mathrm{P}$ & 0 & 0.100 & $\mathrm{ZR} v s \mathrm{P}$ & 0 & 0.100 \\
\hline $\mathrm{ZR}$ vs $\mathrm{CU}$ & 0 & 0.100 & $\mathrm{ZR}$ vs $\mathrm{CU}$ & 0 & 0.100 \\
\hline ZR vs CRZ & 1 & 0.0002 & $\mathrm{ZR} v s \mathrm{CRZ}$ & 1 & 0.0002 \\
\hline $\mathrm{ZR} v s \mathrm{~PB}$ & 1 & 0.0002 & $\mathrm{ZR}$ vs $\mathrm{PB}$ & 1 & 0.0002 \\
\hline $\mathrm{P} v s \mathrm{CU}$ & 0 & 0.100 & $\mathrm{P} v s \mathrm{CU}$ & 0 & 0.100 \\
\hline P vs CRZ & 1 & 0.0002 & $\mathrm{P} v s \mathrm{CRZ}$ & 1 & 0.0002 \\
\hline $\mathrm{P} v s \mathrm{~PB}$ & 1 & 0.0002 & $\mathrm{P} v s \mathrm{~PB}$ & 1 & 0.0002 \\
\hline $\mathrm{CU} v s \mathrm{CRZ}$ & 1 & 0.0002 & $\mathrm{CU} v s \mathrm{CRZ}$ & 1 & 0.0002 \\
\hline $\mathrm{CU}$ vs $\mathrm{PB}$ & 1 & 0.0002 & $\mathrm{CU} v s \mathrm{~PB}$ & 1 & 0.0002 \\
\hline CRZ vs PB & 0 & 0.100 & CRZ vs PB & 0 & 0.100 \\
\hline Global test & & & Global test & & \\
\hline Tissue of $P$. verrucosa & 0.6 & 0.0001 & Sea water & 0.8 & 0.0001 \\
\hline \multicolumn{3}{|c|}{$\begin{array}{l}\text { Pairwise comparisons tissue of } P \text {. verrucosa } \\
\text { among Sites }\end{array}$} & \multicolumn{3}{|c|}{ Pairwise comparisons sea water among Sites } \\
\hline CFS vs ZR & 0 & 0.100 & CFS vs ZR & 0 & 0.100 \\
\hline CFS vs $\mathrm{P}$ & 0 & 0.100 & CFS vs $\mathrm{P}$ & 1 & 0.0002 \\
\hline $\mathrm{CFS} v s \mathrm{CU}$ & 0 & 0.100 & $\mathrm{CFS}$ vs $\mathrm{CU}$ & 1 & 0.0002 \\
\hline CFS vs CRZ & 1 & 0.0002 & CFS vs CRZ & 1 & 0.0002 \\
\hline CFS vs PB & 1 & 0.0002 & CFS vs PB & 1 & 0.0002 \\
\hline $\mathrm{ZR} v s \mathrm{P}$ & 0 & 0.100 & $\mathrm{ZR}$ vs $\mathrm{P}$ & 1 & 0.0002 \\
\hline $\mathrm{ZR} v s \mathrm{CU}$ & 0 & 0.100 & $\mathrm{ZR}$ vs $\mathrm{CU}$ & 1 & 0.0002 \\
\hline $\mathrm{ZR}$ vs CRZ & 1 & 0.0002 & $\mathrm{ZR} v s \mathrm{CRZ}$ & 1 & 0.0002 \\
\hline $\mathrm{ZR}$ vs $\mathrm{PB}$ & 1 & 0.0002 & $\mathrm{ZR} v s \mathrm{~PB}$ & 1 & 0.0002 \\
\hline $\mathrm{P} v s \mathrm{CU}$ & 0 & 0.100 & $\mathrm{P} v s \mathrm{CU}$ & 0 & 0.100 \\
\hline P vs CRZ & 1 & 0.0002 & $\mathrm{P} v s \mathrm{CRZ}$ & 1 & 0.0002 \\
\hline $\mathrm{P} v s \mathrm{~PB}$ & 1 & 0.0002 & $\mathrm{P} v s \mathrm{~PB}$ & 1 & 0.0002 \\
\hline $\mathrm{CU}$ vs CRZ & 1 & 0.0002 & CU vs CRZ & 1 & 0.0002 \\
\hline $\mathrm{CU} v s \mathrm{~PB}$ & 1 & 0.0002 & $\mathrm{CU} v s \mathrm{~PB}$ & 1 & 0.0002 \\
\hline $\mathrm{CRZ}$ vs PB & 1 & 0.0002 & $\mathrm{CRZ}$ vs $\mathrm{PB}$ & 0 & 0.100 \\
\hline Global test & & & Global test & & \\
\hline Mucus of $P$. damicornis & 0.6 & 0.0001 & Sediment & 0.887 & 0.0001 \\
\hline \multicolumn{3}{|c|}{$\begin{array}{l}\text { Pairwise comparisons mucus of } P \text {. damicornis } \\
\text { among Sites }\end{array}$} & \multicolumn{3}{|c|}{ Pairwise comparisons sediment among Sites } \\
\hline CFS vs ZR & 0 & 0.100 & CFS vs ZR & 0 & 0.100 \\
\hline CFS vs $\mathrm{P}$ & 0 & 0.100 & CFS vs $\mathrm{P}$ & 1 & 0.0002 \\
\hline CFS vs CU & 0 & 0.100 & CFS vs CU & 1 & 0.0002 \\
\hline CFS vs CRZ & 1 & 0.0002 & CFS vs CRZ & 1 & 0.0002 \\
\hline CFS vs PB & 1 & 0.0002 & $\mathrm{CFS}$ vs $\mathrm{PB}$ & 1 & 0.0002 \\
\hline $\mathrm{ZR}$ vs $\mathrm{P}$ & 0 & 0.100 & $\mathrm{ZR}$ vs $\mathrm{P}$ & 1 & 0.0002 \\
\hline $\mathrm{ZR}$ vs CU & 0 & 0.100 & $\mathrm{ZR}$ vs CU & 1 & 0.0002 \\
\hline ZR vs CRZ & 1 & 0.0002 & $\mathrm{ZR}$ vs CRZ & 1 & 0.0002 \\
\hline $\mathrm{ZR} v_{s} \mathrm{~PB}$ & 1 & 0.0002 & $\mathrm{ZR}$ vs $\mathrm{PB}$ & 1 & 0.0002 \\
\hline $\mathrm{P} v s \mathrm{CU}$ & 0 & 0.100 & $\mathrm{P} v s \mathrm{CU}$ & 0.2 & 0.0182 \\
\hline P vs CRZ & 1 & 0.0002 & $\mathrm{P} v s \mathrm{CRZ}$ & 1 & 0.0002 \\
\hline $\mathrm{P}$ vs $\mathrm{PB}$ & 1 & 0.0002 & $\mathrm{P} v s \mathrm{~PB}$ & 1 & 0.0002 \\
\hline CU vs CRZ & 1 & 0.0002 & $\mathrm{CU}$ vs $\mathrm{CRZ}$ & 1 & 0.0002 \\
\hline $\mathrm{CU} v s \mathrm{~PB}$ & 1 & 0.0002 & $\mathrm{CU}$ vs $\mathrm{PB}$ & 1 & 0.0002 \\
\hline $\mathrm{CRZ}$ vs $\mathrm{PB}$ & 1 & 0.0002 & CRZ vs PB & 1 & 0.0002 \\
\hline
\end{tabular}


Table B3. One-way similarity analysis (ANOSIM), results from comparing the bacterial OTUs among Substrates within of each Sites in the corals reef ecosystem on Mexican Central Pacific. Code: CFS (Costa Fragata Somero), ZR (Zona de Restauración), P (Pelícanos), TPd (Tissue of P. damicornis), TPv (Tissue of P. verrucosa), M Pd (Mucus of P. damicornis), M Pv (Mucus of P. verrucosa), SW (Sea water) and Sdmt (Sediment) / Resultados del análisis de similitudes (ANOSIM), resultados para comparar los OTUs bacterianos entre Sustratos dentro de cada Sitio en los ecosistemas de coral del Pacífico central mexicano. Códigos: CFS (Costa Fragata Somero), ZR (Zona de Restauración), P (Pelícanos), TPd (Tejido de P. damicornis), TPv (Tejido de P. verrucosa), MPd (Mucus de P. damicornis), MPv (Mucus de P. verrucosa), SW (Agua de mar) y Sdmt (Sedimentos)

\begin{tabular}{|c|c|c|c|c|c|}
\hline Test & $\begin{array}{c}\mathrm{R} \\
\text { statistic }\end{array}$ & $\begin{array}{l}\text { Significance } \\
\text { level }\end{array}$ & Test & $\begin{array}{c}\mathrm{R} \\
\text { statistic }\end{array}$ & $\begin{array}{c}\text { Significance } \\
\text { level }\end{array}$ \\
\hline $\begin{array}{l}\text { Global test } \\
\text { CFS }\end{array}$ & 1 & 0.0001 & $\begin{array}{l}\text { Global test } \\
\text { CU }\end{array}$ & 1 & 0.0001 \\
\hline \multicolumn{3}{|c|}{$\begin{array}{l}\text { Pairwise comparisons among Substrates } \\
\text { within CFS }\end{array}$} & \multicolumn{3}{|c|}{$\begin{array}{l}\text { Pairwise comparisons among Substrates } \\
\text { within CU }\end{array}$} \\
\hline $\mathrm{TPd} v s \mathrm{TPv}$ & 1 & 0.0002 & $\mathrm{TPd} v s \mathrm{TPv}$ & 1 & 0.0002 \\
\hline TPd $v s$ MPd & 1 & 0.0002 & TPd $v s$ MPd & 1 & 0.0002 \\
\hline $\mathrm{TPd} v s \mathrm{MPv}$ & 1 & 0.0002 & $\mathrm{TPd} v s \mathrm{MPv}$ & 1 & 0.0002 \\
\hline $\mathrm{TPd} v s \mathrm{SW}$ & 1 & 0.0002 & $\mathrm{TPd} v s \mathrm{SW}$ & 1 & 0.0002 \\
\hline TPd $v s$ Sdmt & 1 & 0.0002 & TPd $v s$ Sdmt & 1 & 0.0002 \\
\hline TPv vs MPd & 1 & 0.0002 & TPv $v s$ MPd & 1 & 0.0002 \\
\hline $\mathrm{TPv} v s \mathrm{MPv}$ & 1 & 0.0002 & $\mathrm{TPv} v s \mathrm{MPv}$ & 1 & 0.0002 \\
\hline $\mathrm{TPv} v s \mathrm{SW}$ & 1 & 0.0002 & $\mathrm{TPv} v s \mathrm{SW}$ & 1 & 0.0002 \\
\hline $\operatorname{TPv} v s \mathrm{Sdmt}$ & 1 & 0.0002 & $\mathrm{TPv} v s \mathrm{Sdmt}$ & 1 & 0.0002 \\
\hline MPd vs MPv & 1 & 0.0002 & MPd vs MPv & 1 & 0.0002 \\
\hline MPd $v s$ SW & 1 & 0.0002 & MPd $v s \mathrm{SW}$ & 1 & 0.0002 \\
\hline MPd $v s$ Sdmt & 1 & 0.0002 & MPd $v s$ Sdmt & 1 & 0.0002 \\
\hline $\mathrm{MPv} v s \mathrm{SW}$ & 1 & 0.0002 & $\mathrm{MPv} v s \mathrm{SW}$ & 1 & 0.0002 \\
\hline MPv $v s \mathrm{Sdmt}$ & 1 & 0.0002 & MPv $v s \mathrm{Sdmt}$ & 1 & 0.0002 \\
\hline SW vs Sdmt & 1 & 0.0002 & $\mathrm{SW} v s \mathrm{Sdmt}$ & 1 & 0.0002 \\
\hline $\begin{array}{l}\text { Global test } \\
\text { ZR }\end{array}$ & 1 & 0.0001 & $\begin{array}{l}\text { Global test } \\
\text { CRZ }\end{array}$ & 1 & 0.0001 \\
\hline
\end{tabular}

Pairwise comparisons among Substrates $\quad$ Pairwise comparisons among Substrates within ZR

TPd vs TPy

TPd $v s$ MPd

TPd $v s$ MPv

TPd $v s$ SW

TPd vs Sdmt

TPv vs MPd

TPv vs MPv

TPv vs SW

TPv vs Sdmt

MPd $v s$ MPv

MPd $v s$ SW

MPd $v s$ Sdmt

MPv vs SW

MPv vs Sdmt

SW vs Sdmt

0.0002 within CRZ

TPd $v s$ TPv

TPd vs MPd

TPd $v s \mathrm{MPv}$

0.0002

0.0002

0.0002

0.0002

0.0002

0.0002

0.0002

0.0002

0.0002

0.0002

0.0002

0.0002

0.0002

Global test

0.0001

$\mathrm{P}$

0.993

Pairwise comparisons among Substrates within $P$

TPd $v s$ TPv

TPd $v s$ MPd

TPd vs MPv

TPd $v s \mathrm{SW}$

TPd $v s$ Sdmt

TPv $v$ MPd

$\operatorname{TPv} v s \mathrm{MPv}$

$\mathrm{TPv} v s \mathrm{SW}$

$\mathrm{TPv} v s \mathrm{Sdmt}$

MPd vs MPv

MPd $v s$ SW

MPd $v s$ Sdmt

MPv vs SW

MPv vs Sdmt

$\mathrm{SW} v s \mathrm{Sdmt}$

0.0002
0.0002
0.0002
0.0002
0.0002
0.0002
0.0002
0.0002
0.0002
0.0002
0.0002
0.0002
0.0002
0.0002
0.0002

TPd $v s$ SW

TPd $v s$ Sdmt

$\mathrm{TPv}$ vs MPd

$\mathrm{TPv} v s \mathrm{MPv}$

TPv vs SW

$\operatorname{TPv} v s \mathrm{Sdmt}$

MPd $v s$ MPv

MPd $v s$ SW

MPd $v s$ Sdmt

$\mathrm{MPv} v s \mathrm{SW}$

SW vi Sdmt $11-0.0002$

Global test

PB

1

0.0002

0.0002

0.0002

0.0002

0.0002

0.0002

0.0002

0.0002

0.0002

0.0002

0.0002

0.0002

0.0002

0.0002

Pairwise comparisons among Substru within $\mathrm{PB}$

TPd $v s \mathrm{TPv}$

TPd vs MPd

TPd $v s \mathrm{MPv}$

TPd $v s$ SW

TPd $v s$ Sdmt

TPv $v s$ MPd

$\mathrm{TPv} v s \mathrm{MPv}$

TPv vs SW

TPv vs Sdmt

MPd $v s \mathrm{MPv}$

MPd $v s$ SW

MPd $v s$ Sdmt

$\mathrm{MPv} v s \mathrm{SW}$

MPv $v s$ Sdmt

SW vs Sdmt

Vol. 52, N², 2017 
Table B4. Variables that explain the variation of the bacterial OTUs in the corals reef ecosystem on Mexican Central Pacific. Code: CFS (Costa Fragata Somero), ZR (Zona de Restauración), P (Pelícanos), CU (Cuastecomatito), CRZ (Carrizales) and PB (Punto B). LCC (live coral cover), RSC (sponge), FM A (fleshy macroalgae), SAL (salinity) and \%TA (percentage of sandy texture) / Variables que contribuyeron a la variación de los OTUs bacterianos en los arrecifes de coral del Pacífico central mexicano. Códigos: CFS (Costa Fragata Somero), ZR (Zona de Restauración), P (Pelícanos), CU (Cuastecomatito), CRZ (Carrizales) y PB (Punto B). LCC (coral vivo), RSC (esponjas), FMA (macroalgas carnosas), SAL (salinidad) y \%TA (porcentaje de textura arenosa)

\begin{tabular}{clcccccc}
\hline \multirow{2}{*}{ Variables } & \multirow{2}{*}{ Season } & \multicolumn{7}{c}{ Sites } \\
\cline { 3 - 8 } & & CFS & ZR & P & CU & CRZ & PB \\
\hline \multirow{2}{*}{ LCC } & Summer & 31.8 & 26.3 & 24.2 & 47.7 & 53 & 11.6 \\
& Winter & 31.8 & 26.3 & 24.2 & 47.7 & 53 & 11.6 \\
RSC & Summer & -- & -- & -- & 0.3 & -- & 4.2 \\
& Winter & - & -- & - & 0.3 & -- & 4.2 \\
FMA & Summer & 10.4 & 17.96 & 0.8 & 7.4 & 25.3 & 14.3 \\
& Winter & 10.4 & 17.96 & 0.8 & 7.4 & 25.3 & 14.3 \\
SAL & Summer & 36.5 & 36.3 & 35.9 & 36 & 35.7 & 35.6 \\
& Winter & 36.5 & 36.3 & 35.9 & 36 & 35.7 & 35.6 \\
\%TA & Summer & 74.8 & 63.8 & 64.4 & 67.1 & 81.4 & 73.5 \\
& Winter & 76.3 & 62.1 & 67.8 & 71.9 & 79.1 & 77.1 \\
\hline
\end{tabular}

